Minnesota State University, Mankato

CORNERSTONE

Minnesota State University mankato
Cornerstone: A Collection of Scholarly and Creative Works for Minnesota

State University, Mankato

\title{
Victim Blaming, Protests, and Public Space: News Coverage of the Occupy Wall Street Sexual Assaults
}

\author{
Abigail Barefoot \\ Minnesota State University - Mankato
}

Follow this and additional works at: https://cornerstone.lib.mnsu.edu/etds

Digitadrt of the Women's Studies Commons

Commons

\begin{abstract}
Network Recommended Citation

Barefoot, A. (2014). Victim Blaming, Protests, and Public Space: News Coverage of the Occupy Wall Street Sexual Assaults [Master's thesis, Minnesota State University, Mankato]. Cornerstone: A Collection of Scholarly and Creative Works for Minnesota State University, Mankato. https://cornerstone.lib.mnsu.edu/ etds/288/
\end{abstract}

This Thesis is brought to you for free and open access by the Graduate Theses, Dissertations, and Other Capstone Projects at Cornerstone: A Collection of Scholarly and Creative Works for Minnesota State University, Mankato. It has been accepted for inclusion in All Graduate Theses, Dissertations, and Other Capstone Projects by an authorized administrator of Cornerstone: A Collection of Scholarly and Creative Works for Minnesota State University, Mankato. 
Victim Blaming, Protests, and Public Space: News Coverage of the Occupy Wall Street Sexual Assaults

\author{
By \\ Abigail Barefoot
}

A Thesis Submitted in Partial Fulfillment of the

Requirements for the Degree of

Masters of Arts

In

Gender and Women's Studies

Minnesota State University, Mankato

Mankato, Minnesota

May 2014 
Victim Blaming, Protests, and Public Space: News Coverage of the Occupy Wall Street Sexual Assaults

\section{Abigail Barefoot}

This thesis has been examined and approved by the following members of the student's committee.

Dr. Laura Harrison, Advisor

Dr. Amy Sullivan

Dr. Barbara Carson 


\begin{abstract}
An abstract for the thesis of Abigail Barefoot for the Master of Arts in Gender and Women's Studies at Minnesota State University, Mankato, Minnesota.
\end{abstract}

Title: Victim Blaming, Protests, and Public Space: News Coverage of the Occupy Wall Street Sexual Assaults

Occupy Wall Street was a national protest centered on wealth redistribution and sparked a national dialogue about economic reform. The movement faced internal challenges of crime occurring in the camps including sexual assault; this crime was covered by news outlets as part of their Occupy Wall Street coverage. This thesis will expand upon previous feminist research on sexual violence news coverage by using a feminist media analysis to examine the coverage of sexual assaults occurring during Occupy Wall Street. Previous feminist research on sexual assault coverage argues that newspapers use myths about rape to discredit the crime and blame the victim. I argue that the coverage of sexual assaults during Occupy Wall Street used a "blame the victim" narrative to link the participation of women protesting in public space to gender based violence. I will explore how the actions of activists, the physical space of Occupy camps and the lack of crime prevention of the protesters and police were used by reporters to shift the blame from the perpetrator onto the victim. News coverage is considered an objective source of information so biased narratives of sexual assaults can reinforce society's traditional ideology about sexual assault, which can affect the needs of survivors. 


\section{Table of Contents}

\section{Chapter 1}

Introduction

\section{Chapter 2}

Literature Review

Rape Culture and Rape Myths

Coverage of Sexual Assault 19

Activism, Public Space, and Gender

26

\section{Chapter 3}

Methodology

\section{Chapter 4}

Analysis

Direct and Indirect Coverage__ 44

Guilty by Association__ 46

No Place For Women $\quad 55$

On Your Own

\section{Chapter 5}

Conclusion

\section{Appendix}

Occupy's Statement on Sexual Assault 87 Newspaper Articles Examined 


\section{Chapter 1: Introduction}

In October of 2011, the media began covering the thousands of protesters camping in Zuccotti Park calling themselves Occupy Wall Street. With their battle cry of "We are the 99 percent" Gitlin argues in Occupy Nation: The Roots, the Spirit, and the Promise of Occupy Wall Street that the purpose of this social movement was to bring awareness to economic inequality in which 99 percent of the wealth in the United States is controlled by one percent of the population (Gitlin 50). The name Occupy Wall Street signified the occupation of the space outside of Wall Street (a prime financial center of New York City) by protestors who set up tents and refused to leave the location (Gitlin 26). As more and more protestors flocked to the camps, the movement broadened its goals to include a wide variety of issues including genetically modified food, housing foreclosure, and student loans. The researchers DeLuca, Lawson, and Sun argue that news pundits bickered over the credibility of the movement because it lacked clear-cut

goals (491). The coverage of the movement varied from newspaper to newspaper, but the framing of coverage continued to describe the movement as large but disorganized, with no signs of stopping. As Occupy Wall Street gained momentum, the public became aware of sexual assaults occurring within the Occupy camps. As a result of this information, media began reporting on these assaults as part of their Occupy Wall Street coverage.

This project employs a feminist media analysis of mainstream newspapers to explore the discourse of sexual assault and women protesting in public space. Women face challenges when occupying public space because men are ideologically associated with the public sphere and women with the private sphere. This leads to women under 
tight scrutinization of their behavior in public space, which can be linked to how their sexual assaults in public space are represented. Typically, the media relies upon a discourse of sexual assault that either implicitly or explicitly blame the victim (Bennedict 18). Blame the victim myths center on the belief that sexual assault is an individual problem in which women in particular can stop rape from happening by monitoring their behavior, dress or location. Blame is placed on women who are sexually assaulted by questioning why they failed to stop rape from happening (Lonsway, and Fitzgerald). Feminist researchers Marian Meyers, Helen Benedict, and Cynthia Carter argue that blame the victim narratives are prevalent within news coverage of sexual assault where the fault is placed on the victim rather than the perpetrator. Using this research, I hypothesized that the narratives used to cover Occupy Wall Street would mirror similar victim blaming narratives used in news coverage.

What I found was a more complex understanding of how social movements shape sexual assault coverage. I argue that the coverage of sexual assaults during Occupy Wall Street used a non-traditional "blame the victim" narrative to link the participation of women protesting in public space to gender-based violence. This coverage focused less on the victims themselves, but used perceptions of Occupy Wall Street to blame the women involved instead of focusing on traditional victim blaming methods such as the analyzing women's clothing or their sexual history. Occupy Wall Street was used to stand in for these traditional forms because women were presented as not belonging in Occupy Walls Street's political environment. Highly negative views of Occupy Wall Street and assumptions about women's role in public space were used to blame the victims in addition to the traditional focus on what the victim was wearing or her prior sexual 
experiences.

Coverage of sexual assaults has serious implications, including how society responds to sexual assault. Individuals both receive and interpret knowledge from the media, which means that media's messages help the public to create informed opinions on social issues. Mainstream news coverage is believed to be objective and truthful by the general public, so the messages society receive from news coverage encourages rape culture and upholds biased views of sexual assault that can have serious effects on survivors (Franiuk 300) . These effects include how likely a survivor is to come forward with his or her assault, what people's attitudes are about sexual assault, and how the public interacts with survivors of violence (Franiuk 302). If the goal of feminists is to end gender-based violence, we must look at how dominant news outlets shape messages of sexual assault.

Not only does the Occupy Wall Street sexual assault coverage have repercussions for rape survivors, but also for women involved in social protests. Victim blaming narratives in the mass media sends messages that women's place is not at protests because they are unsafe. The victim blaming messages can hinder women's participation in larger social movements because of the fear of sexual assault. This fear of sexual assault is a central component of sexual terrorism, a system by which males frighten, and by frightening, dominate and control women. The threat of violence by men is used to severely limit the freedom of women and makes women dependent on men for their own safety (Herman 45). These articles about Occupy Wall Street incorporating this fear of rape by using ongoing rapes in the camps to hamper women's participation in the movement. By exploring the connections between women's occupation of public space 
and sexual assault coverage, this project will demonstrate how pervasive and intertwined society's understanding of sexual assault and women's role in social movements are in the United States.

\section{Timeline of Occupy Wall Street}

In order to analyze the coverage of the Occupy Wall Street sexual assaults, it is important to have an understanding of the movement. Van Gelder argues in This Changes Everything: Occupy Wall Street and the 99\% Movement that while the movement lasted only three months from September 17, 2011 to November 15, 2011, but the message of Occupy continues today (Van Gelder 14). Occupy Wall Street was different from more conventional forms of social change. Rather than having a set committee in charge of the leadership of the group, Occupy used a horizontal assembly method in which there is no hierarchy of leadership, but everyone had equal opportunities to speak and plan the movement. One way this was utilized was making decisions by consensus through direct democracy and general assemblies (see DeLuca, Lawson, and Sun; Gitlin; Van Gelder). This is not a new tactic and has been utilized within the Civil Rights Movement and Students for a Democratic Society (Gitlin 23). However, these tactics were given national attention through media coverage of Occupy Wall Street. Direct democracy was presented as innovative and new because Occupy Wall Street was a mass protest that did not follow the norms of traditional social movements.

This movement did not appear out of nowhere or in a vacuum - it was influenced by the work activists were already doing at the time, such as the protesters participating in what was known as the "Arab Spring," the large scale grassroots revolution that began in Tahrir Square in Cairo, Egypt (Van Gelder, 16). In the case of Occupy Wall Street, 
what was thought of as a spontaneous movement actually was mapped out several months before the occupation. It is important to note that there is some discrepancy between who started the movement, with some sources citing the anti-capitalism magazine Adbusters (Gitlin) as having given birth to the movement. Other participants in the movement believed it was the work of many groups, including New Yorkers Against Budget Cuts, activists that were already in the process of creating a "sleep in" on income inequality after Mayor Bloomberg's deep budget cuts to public services (Van Gelder 17). Both groups were already doing smaller occupations and demonstrations in Wall Street months before the movement took off.

However, the spark of the movement began with Adbusters calling for people to meet on September 17, 2011 with a poster of a ballerina on top of the bull in Wall Street with the text:

What is our one demand?

\#Occupy Wall Street

September 17

Bring tent (Van Gelder 1).

The date was set and groups decided to come together and occupy. Originally, the protesters were going to occupy One Chase Manhattan Plaza and Bowling Green Park, but the police were informed of the protest and the areas were fenced off. This led protesters to Zuccotti Park, a public park that is privately owned. This created a gray area, in which the space was both private and public, which protesters took advantage of in their occupation. The first day of the protest only featured a few dozen protesters who seemed to have no clear knowledge of what was going to happen with the movement. A day became days, then turned into weeks. Activists did not know how long the movement 
would last, but they showed no signs of leaving the area (Gitlin 3). During the first few weeks, the scholars, DeLuca, Lawson, and Sun argued that mainstream media was not reporting on the camps in what was considered a "media blackout" (491). It was through social media that the public began to learn about the movement, and how people began coming to Zuccotti Park. It was not until September 27, day 11 of the protest that the press began to take notice of the camps (Gitlin 23). This inspired even more individuals to congregate at Occupy Wall Street, swelling the numbers of protesters within the camp.

In October, the second month of the protests, clashes between police and protesters became more intense as reported through newspaper coverage. This led to the climax on October 14 when New York City mayor Michael Bloomberg attempted to have the protesters removed from the location, in a so-called temporary eviction to clean the space, but the city was unable to eject individuals from the park (Van Gelder 37). Over 5,000 protesters stayed in the park ready to be forcibly removed. By 7 a.m., officials decided to back down, and the protests continued. The following day was stated as “Global Change Day" in which 952 cities in 82 countries protested against "income inequalities, corrupt politicians and economies rigged to benefit the wealthy at the expense of everyone else" (Van Gelder 21).

In the third and final month of the movement, the public became increasingly aware of the violence in Occupy and the disruption of daily life that Occupy Wall Street was creating through news reports of violent activity in the camp. It was also in these weeks that reports of sexual assaults in the camp began to surface (Gitlin 39). Due to the scattered and non-hierarchical organization of Occupy Wall Street, it is unclear how many sexual assaults occurred in the Occupy camps. There is no official data from the 
camps and Occupy stated that many women decided to deal with the perpetrators on their own rather than reporting to the police (wwwoccupywallst.org). However, the actual numbers of assaults are not necessary for this research because the news media from The New York Daily News, The New York Times and The Wall Street Journal made this issue into a pressing concern and presented it as a crisis. Occupy Wall Street responded by releasing a statement entitled "Transforming Harm \& Building Safety: Confronting Sexual Violence At Occupy Wall Street \& Beyond" about sexual assaults in the camp (see Appendix A for the full statement from Occupy Wall Street).

The statement Occupy released challenged the media's coverage of a particular sexual assault case, stating it was blaming the victim and used to discredit Occupy. "We are concerned that segments of the media attempted to use this incident as another way to disingenuously attack and discredit OWS. It is reprehensible to manipulate and capitalize on a tragedy like this to discredit a peaceful political movement." This shows that Occupy Wall Street was aware of problematic representation of the movement and the sexual assault survivors presented by news media.

Occupy Wall Street used their statement to acknowledge that sexual assault was a societal problem, and discussed how the movement handled sexual assault. "The survivor has been surrounded by a network of allies and trained advocates... at every step of the process and in line with the core principles of survivor support, her wishes as how to proceed have been honored" (Occupywallst.org). By giving a statement, Occupy Wall Street attempted to shed light on their practices and their lack of tolerance towards sexual assault.

Even though Occupy tried to present itself as a peaceful movement, growing 
concerns over violence in the park forced an intervention. On November 15 around 1 a.m., police began clearing the park. The official statement released by Mayor Bloomberg's Office said, "This action was taken at this time of day to reduce the risk of confrontation in the park, and to minimize disruption to the surrounding neighborhood" (Mayor Bloomberg's Office). According to official statement by Bloomberg, the occupation had to end because it was starting to pose a health and fire safety hazard to the protestors and to the surrounding community. Protesters tried to reoccupy the park several times beginning with 30,000 protesters the next day (Gitlin 45). When reoccupying failed, protesters argued that the occupation was a form of free speech, protected under the First Amendment, and tried to take the issue to court. However, the case was dropped after lawyers argued occupation was not a protected form of free speech. Since then Occupy tried to retake the park several times, each time unsuccessfully. However, the spirit of Occupy continues with grassroots organizing in various communities, and activism focusing on single issues that Occupy addressed such as immigration reform, or focusing on the reforming bank bailouts (Gitlin 56).

While Occupy lasted only a few months, it is an iconic moment that I believe will have a lasting effect on America's history. Not only did it bring nationwide attention to a discussion on economic inequality and challenge the way we think about social movements, but it also was a movement that reintroduced the nation to the idea that people can make a difference. Because of its significance in the $21^{\text {st }}$ century, I believe it is vital to explore how women's actions in the movement were intertwined with news coverage of the sexual assault. It is at this moment we can see how ideology about women's participation in public space and our understanding of sexual assault influence 
one another in our society.

\section{Organization of the Chapters}

In chapter two, I contextualize my research within the existing scholarship. The literature review consists of three main sections: Rape Culture and Rape Myths, Coverage of Sexual Assault, and Activism, Public Space, and Gender. The rape culture and rape myths section address rape myths, sexual terrorism, and how blame the victim narratives influence perceptions of public space. The section on news coverage of sexual assault explores how blame the victim myths manifests themselves in news coverage, and how biased coverage impacts public perceptions of rape. My final section on public space and gender reviews literature on women's access to public space, repression of women in social movements, and how women enter public space.

The methodology discussion in chapter three explains my rationale for analyzing the Occupy Wall Street sexual assault news coverage through a media analysis, and the scope of the project. The methodology chapter also explains the importance of a media analysis guided by feminist principles and addresses the limitations of the project.

Additionally, I acknowledge the importance of reflexivity and how my own positionality influences this thesis project.

In chapter four, I explain the two types of coverage, indirect and direct, that were used by the press to discuss the sexual assaults occurring within Occupy Wall Street. Through these two types of coverage, I demonstrate three forms of blaming the victims for their sexual assaults. These forms use traditional ideology about gender to victimize women for being at the scene of Occupy Wall Street. The themes focus on the men of Occupy Wall Street as deviant, the physical space of Occupy as unfit for women, and the 
lack of support for victims within the camp. I argue in this chapter that the fear of sexual assault was used to hinder women from participating through using sexual assault as an argument of why the Occupy movement should end. Finally, chapter five concludes this thesis with what my analysis coverage means for research on sexual assault news coverage within the wider frame of protests, and includes suggestions for future research. 


\section{Chapter 2: Literature review}

Occupy Wall Street not only created a national dialogue about economic inequality, but challenged United States citizens' understanding of social movements. An unforeseeable outcome of the protests was how conversations about the sexual assaults within the Occupy Wall Street camp intertwined with ideology about women's participation in public space. News coverage of the events used women's participation in the movement to blame the victims for their sexual assault. This literature review will demonstrate that both women's fear of rape and representations of sexual assault in the media are used to limit women's full participation within the public sphere. I will focus on providing an overview of rape culture and rape myths, media coverage of sexual assault, and conceptions of women's participation in public space.

\section{Rape Culture and Rape Myths}

In order to understand how news coverage of the Occupy Wall Street sexual assaults reinforced a "blame the victim" narrative, it is important to recognize the role of these rape myths and how they are related to the larger problem of rape culture. This section reviews feminist literature on how "blame the victim" myths are used in rape culture. Lonsway and Fitzgerald and others argue that these rape myths make sexual assault appear to be less of a problem by reducing the blame of the perpetrator and placing the responsibility of the crime on the victim.

\section{Rape Culture}

Rape myths do not appear out of nowhere, but are a function of rape culture, Buchwald, Fletcher and Roth explain that, "Rape culture is a complex set of beliefs that 
encourages male sexual aggression and supports violence against women" (xi). In this way, violence against women is seen as the norm, rather than a problem. Bevacqua's analysis of rape culture broadens the definition of rape culture to include male privilege. "Sexual assault is tolerated, violent and sexual images are intertwined, women are blamed for being raped, sexist attitudes prevail, and male sexual privilege goes unquestioned" (Bevacqua 9). Rape culture is more than the act of rape itself, it is the historical, cultural, and institutional ideologies that both support and condone the occurrence of rape. Rape culture is not just about a crime committed against a woman, but rather an interlocking system of institutions that normalize and support male violence against women. A key idea of rape culture is that violence is normalized and women are taught to be in constant fear of rape. This is linked to the idea of sexual terrorism, a system by which males frighten, and by frightening, dominate and control women (Sheffield 171). Sexual terrorism operates to provide support and legitimization for those who act out their contempt for women.

Much of the earlier feminist research on rape culture focuses on men as the sole perpetrators of the problem. Cahill argues that this is too simplistic and falls into the women as victims paradigm (Cahill 3). Instead of seeing men as the only perpetrators of the problem, Cahill argues that it is important to remember that women are participants in rape culture as well. "Women are not just victims of that culture, but they are members of it (though secondary). Women are not outside of the culture, but a part of it" (Cahill 4). Scholars cannot just look at men as the problem, but also look at how women perpetuate rape culture as well. One way women participate in supporting rape culture is through the continuation of using rape myths to discredit the crime of rape as a serious issue. 


\section{Rape Myths}

Lonsway and Fitzgerald define rape myths as "attitudes and beliefs that are generally false but widely and persistently held and that serve to deny and justify male aggression against women" (134). Some examples of rape myths include: women asked to be raped by how they dress or act, women can expect rape to happen in public, and women should avoid drinking to stop rape from happening. In fact, rape myths justify violence against women by minimizing the violence men do, and putting more pressure on women to prevent violence it themselves. While empirical evidence shows that these rape myths do not protect women from being raped, Edwards et al. argues that rape myths are perpetuated in institutions including religion, legal systems, and media to continually reinforce and to uphold unequal power relationships (763). Rape myths are not created out of thin air, but constructed to make the crime of rape less of a societal problem and more of an individual problem (Lonsway, and Fitzgerald 136). Rape is viewed as something that happens to someone else, rather than something that could happen to anyone.

It is also important to focus on the gendered aspect of how rape myths are used. Women use rape myths such as "some women ask to be raped" as a way to distance themselves from rape by following procedures that will stop rape from happening to them, such as limiting flirting or refusing to engage in sexual behavior (Ryan 778). Lonsway and Fitzgerald would agree with Ryan, stating that, "The usage of rape myths provides many functions including denying personal vulnerability of all women by suggesting that only other women are raped" (136). However, because women use these rape myths to protect themselves, women face guilt, self-blame and shame when they are 
raped (Sheffield 182). Women who are raped believe that they deserved it, or it was not real rape because their sexual encounter did not mirror rape myths. These myths include seeing only strangers as perpetrators that the victim was asking for it with their dress or mannerism, or that intimate individuals cannot rape their partners (Ryan 778). Rape myths are used to legitimize male violence against women because they put more focus on women to stop rape, and does not represent all male violence as rape.

While women use rape myths as a reason for protecting themselves, men use rape myths to rationalize and justify tendencies towards male aggression (Ryan 775). Rape culture makes violence within sexual intercourse seem to be normal male behavior rather than rape. This is harmful in that it essentializes men as violent and suggests that they cannot control their behavior. In response to Edwards's paper, Ryan argues that rape myths create "rape scripts" in which individuals only see violent rape committed by a stranger as rape (Ryan 778). This makes it harder for women to prove their assault in the case of marital or acquaintance rape because the victim had "assumed the risk" rather than understanding it to be non-consensual (Herman 50). Rape myths encourage individuals to believe only certain behaviors are rape, which delegitimizes the experiences of certain women. Rape myths were a central component of the coverage of the Occupy Wall Street sexual assault in which the perceptions of the movement were used to portray the protestors as potential rapists and the camps as an area where rape was more likely to occur than outside Zuccotti Park.

\section{Blame the Victim}

Lonsway and Fitzgerald highlight three categories of rape myths: denial of rape's existence, excusal, and denial of rape's seriousness (138). I will focus on the category of 
excusal, which centers on the blaming of the victim and treating the rapists' behavior as understandable. This category is most commonly referred to as "blame the victim," and I will refer to it as such in this thesis. This is central to my argument on how blaming the victim is linked to consequences of women occupying public space. The news coverage presented the victims as foolish for participating in Occupy Wall Street thus deserving the sexual assault.

In blame the victim myths, blame of the man is reduced because the female victim's actions led him on. Edwards et al. argues that excusal myths center on historical ideas of women's respectability and expectations about womanhood. This means portrayals of victimhood must match up with gender roles, including traits of passivity and submissiveness (766). Blame the victim myths police women's bodies and behaviors to keep women in their traditional gender roles (Edwards et al. 766). This policing of women's bodies means women do not get to claim the label of a "good woman" but rather men decide who is worthy of the title. Likewise, men are the ones who can take away the title, meaning women must constantly strive to acquire and maintain "good woman" status (Sheffield 173). In the case of news coverage, it is the press who decides who is a good woman or a bad woman in relation to the victim's sexual assault. Cahill argues that the policing of women's actions are not just done by men, but by women for their own safety. Women are expected to monitor, police, restrict and even hinder their movements to attempt to ensure the safety of their bodies (Cahill 135). Sheffield argues that when this self-policing fails to stop rape, women are forced to classify themselves as bad women or convince themselves it was not really rape. When women fail to uphold ideal victimhood, blame is immediately cast on them and off the perpetrator. This 
contextualizes rape to be seen as something that happens to people on an individual level rather than a societal problem.

\section{Rape Myths and Race}

Cahill argues that early 1970s feminist research on rape ignored intersectionality, and the fact that women of color face higher rates of violence than white women. The theory of intersectionality, coined by Kimberle Crenshaw, argues that the intersections of multiple identities overlap to create individuals' experiences with the world as it relates to privilege and oppression. In this way, experiences do not center on one identity factor but on the multiplication of various identities that occur simultaneously. Crenshaw argues that when looking at sexual assault, it is important to understand that women have different identities such as race, immigration status, and class, that can hinder their access to services and support as it related to gender based violence. By taking an intersectional approach and acknowledging other identity factors, feminists can challenge essentialism and refute the claim that women face the same discrimination (1241). By ignoring the racial differences among women, theorists failed to recognize how violence against women operates differently for women of different races. Feminists like Stanko acknowledge this lack of intersectionality in the research, but argue that it is not a limitation, but an understanding that all women have "a common awareness of their particular sexual vulnerability" (161-162). This means that while women of color do face unique challenges as it relates to sexual assault, feminists can essentialize women's experiences of rape together because it is a common fear of all women. Though Stanko is right that women are all likely to have a fear of violence, the foundations of rape myths are constructed from racist stereotypes that put women of color at a disadvantage when 
reporting their rape. The idea of a "good" victim is classified through a white, upper-class lens that women of color can never achieve (Edwards et al. 776). The only women whose sexuality and purity that matters to people in power are the ones that represent the ideal woman, coded by the dominant group in power.

Centered on racist and colonialist ideology, black women historically were seen by white citizens as inherently inferior and could never achieve goodness. George and Martinez argue that black women have been stereotyped as more sensuous, permissive, and promiscuous than white women (110). This linking of sexuality and race means that women of color cannot be good women because they are defined by their sexuality and supposed promiscuity. While it is difficult for any woman to overcome a blame the victim narrative, it is especially hard for women of color, who must deal with both sexism and racism.

Race is an important component of understanding how rape myths are used. However, the coverage of Occupy Wall Street sexual assault did not give background on the identities of the victims. We do know that the composition of Occupy Wall Street was $81 \%$ white and $61 \%$ male (OccupyWallSt.org). Women of color were in the minority of the movement, which made them invisible in the news coverage of the event as compared to white women. While important to the understanding of rape myths, race will not be a central focus of my analysis because it was largely dismissed in news coverage of the events.

\section{Rape Myths and Public Space}

Blame the victim myths demonstrate that women must behave in a certain way to 
avoid violence. This does not only have serious implications for survivors of violence, but also for the daily lives of women. Rape myths are used to limit women's participation in the public sphere. Even though many scholars argue that women are much more likely to face violence inside the home than in public, women change their behavior to protect themselves from the fear of rape in public (Cordon 102-103). Women are much more likely than men to develop avoidance or self-exclusion strategies, even though men are more likely to experience violence in the public sphere (Stanko 156). Valentine argues that tactics such as avoiding certain streets or accessing public space during certain times give women a restricted use and occupation of public space (386). An example of this is a study conducted by Condon, which found that 44.75 percent of women surveyed and interviewed in mainland France were scared to go out alone and 53 percent were afraid to go through certain neighborhoods and streets (125). Gordon and Riger argue that it is not just where women go in public that is limited, but who they interact with, such as offering and accepting rides, talking to others, or accepting help (14). Women's fear of rape serves to limit women's participation in public space. The news coverage of the Occupy Wall Street sexual assaults connected women's occupation of the park with being assaulted by their fellow protesters. The way the coverage was presented suggested that women could not be safe while participating in Occupy Wall Street, and their involvement in the movement should be limited.

Rape myths are pervasive in our society and function to delegitimize the experiences of women who have been raped. Using blame the victim myths reinforces traditional femininity and limits women's participation in public space. How do individuals learn these rape myths and how do they gain legitimacy? One key area of 
perpetuation and reinforcement of blame the victim myths can be found in news coverage of sexual assault.

\section{Coverage of Sexual Assault}

One way rape myths are given validity is through news coverage of sexual assault cases. Unlike fictional accounts of sexual assault that occur in movies or television shows, news coverage of these events is seen as credible and reliable information. However, literature from feminists such as Benedict, Meyers, and Carter show that because of the structure of news gathering, ideas about "newsworthiness," and internal bias of reporters, news media presents a skewed view of rape that is more likely to blame the victim. These distorted myths are used to sway public opinion on rape cases and sexual assault in general.

\section{The Construction of News}

The structure of how journalists construct news produces an environment that allows for a slanted representation of rape. Meyers argues that only certain cases of rape are reported on because they meet the requirements of newsworthiness, such as oddity, conflict, and human interest (21). Carter explains that only reporting on cases that meet the requirements of newsworthiness creates a situation where "the extraordinary become ordinary" in which only the most outrageous cases of sexual assault are reported on (219). One example of this would be the Stubenville football team case in 2012, in which a high school football team raped an intoxicated girl and posted videos of it onto social media. This distortion is not limited to sexual assault cases, but most types of crime. Meyers argues that crime news itself is a hierarchy where the more frequent types of crime are reported on less frequently because they are seen as common occurrences and a 
part of everyday life and are not worth reporting. In the case of rape, only the most dramatic or sensational cases are presented (Meyers 23). This means only a fraction of experiences women have are represented in the news.

Rape is considered part of crime news, but fails to exclusively follow the construction of crime as deviance, or the idea that criminals are deviants acting outside the limits of acceptable social behavior (Meyers 23). "Although the crime as deviance theory claims that the news defines and ostracizes the criminal as deviant, studies of news coverage of violence against women indicate the news positioning of the female victim as deviant and deserving of condemnation if she appears to have disregarded or flaunted gender role expectations" (Meyers 24). This shows a link to rape culture in which the man is not considered a deviant for his behavior, but rather the woman must be blamed for her actions. Benedict argues that victims of sexual assault are marked as a victim in relationship to eight factors, including deviation from the traditional female sex role, whether she knows the assailant, and her physical features (19). While these factors are not deviant behaviors on their own, they become deviant when a sexual assault occurs. Women participating in social movement have their actions judged using similar criteria and is used to hurt their credibility. In the case of the Occupy Wall Street sexual assaults, journalists used women's participation in the movement as a sign of deviant behavior in relationship to Benedict's factors. Rape myths in journalism and in the Occupy coverage are constructed using details about the crime, and the language used to describe the crime and who is used as sources.

\section{Ways Blaming the Victim Takes Place in News}

One way credibility of the victim is distorted is by the use of sources. Sources are 
individuals interviewed for a news article and can either reduce or build credibility. Benedict argues that journalists use these sources to hide behind their biased reporting by blaming rape myth usage on sources rather than their reporting (Benedict 265). "Facts" and sources can be used to discredit the victim by finding past information or gaps in her story to discredit her. Journalists turn to sources for information about the victim and publish unflattering representations without looking for contradicting information (Carter 225). For example, if a source states that the victim was well known for being promiscuous, reporters may fail to look for another source to confirm that story, or find someone who disagrees with that subjective view from the source. In addition, because news is seen as objective, reporters seek out sources that represent objective viewpoints. These official experts include police officers and lawyers, who have a stake in the sexual assault cases (Meyers 22). Because men are seen as more credible, Carter argues that, men are more frequently used as sources than women. When women are used as sources, they are used to invoke emotions after men have been used to establish authority on the crime (Carter 227). This means that not only are news stories shaped by men, but violence against women is seen and told through men's eyes. In the case of Occupy Wall Street, men were more frequently interviewed about violence in the park and discussing the safety of women in the park, which silenced many of the victims' voices.

This is especially true when looking at who is speaking on behalf of the victim. While rape shield laws work to protect the victim by limiting a defendant's ability to cross-examine rape victims about their past sexual behavior, Moorti argues that the victim "is constantly spoken of but herself remains inaudible or inexpressible; she is displayed as a spectacle but remains unrepresentable" (110). Benedict disagrees with 
Moorti and argues that rape shield laws help protect the victim from further victim blaming by shielding her identity from the press. However, she does argue that reporters should focus more on the crime itself than information about the victim (264). Meyers argues that sexual assault advocates are torn between anonymity and putting a face on the victim. Nonetheless, she does point out that the most import thing is to protect the victim, honor her wishes, and see the victim as a human (Meyers 111).

There is also a lack of balance in the reporting of details of the assailant and the victim. Supplementary details of the survivor's life are used in the reporting, even if they have no relevance to the case (Benedict 260). Meyers argues that details are used not just in relationship to the victim's personal life, but the events of the crime itself that the public does not need to know. "Advocates gave numerous examples of stories in which details should have been left out because they were unnecessary and served primarily to embarrass or re-victimize the woman" such as stating that the victim's underwear was stolen by the perpetrator (Meyers 111). Cuklanz agrees with Meyers stating that, "the fragmented nature of news perpetuates traditional stereotypical views of sexual assault by discussing many elements out of context" (50). Kitzinger also discusses that the fragmented way of presenting sexual assault by arguing that the formatting of news reporting tends to focus on events rather than issues, which leads little room for exploration of theoretical issues or discussing solutions to the problem (20).

Newsworthiness focuses on the oddity and sensational details of the crime which can be used to blame the victim and present a skewed view of why rape happens. Details of the crime and victim are used to make headlines, regardless if the public needs to know the information. 
While sources are used to shape the character of the victim, the language of the news can also be used to blame the victim. Benedict argues that women in the news are described in ways that men are not, including adjectives about physical attractiveness, their relationship to men and linking behavior to sexuality (20). These words are not only “consistently sexual, condescending or infantilizing," but can blame the victim (Benedict 20). News coverage can also blame the victim by statements that question why a crime occurs. Meyers states, "These myths or assumptions are embedded in the journalistic 'why' of a story and ask why was a woman raped, beaten or murdered - was it something she said or did?" (Meyers 63). The sentiment is that the victim's choices could have stopped the crime from occurring. Finally, language can make the crime seem less harsh than it really is. Meyers argues that men's behavior or actions are masked through obscure language such as "fondling" rather than assaulting to excuse the assailant and discredit women (Myers 109). Benedict would agree with Meyers arguing that using words like "had sex with" lessens the crime because it is associated with consent rather than a crime being committed (260).

Feminists have also critiqued the use of passive voice when discussing sexual assault cases. In the "Grammar of Male Violence," Jennie Ruby argues that passive voices allows women to be seen as the victims and ignores the role the perpetrator played in the crime (26). For example, newspapers will state "a woman was raped" rather than "a man raped a woman." This language allows for the conversation about rape prevention to focus on women, leaving the perpetrators with little accountability (Ruby 26). Meyers takes this argument a step further and argues that obscuring men's behavior or actions removes the context of power and control that is central to issues of violence 
against women (110). In all of these cases, language is used to diminish the crime through word choice.

\section{How Biased Coverage Impacts Perceptions of Rape}

It is important to remember that not only do victim blaming narratives from the press hurt the individual women they report on, but society as a whole. Newspapers serve a crucial role in teaching women about the potential dangers of sexual violence, however, this education is presented through rape myths and extraordinary cases that harm women more than help women (Carter 231). Franiuk found that individuals who read articles featuring rape myths were more likely to side with the assailant than with the victim (298). Gordon and Riger argue that news coverage of rape “enhances women's fears and leaves misleading impressions of both the crime and how it could be dealt with" (132). One way this education takes place is by using women as a cautionary tale of what could happen. Meyers argues that news reports act as a warning and a form of social control that outline the boundaries of acceptable behavior and the consequences are for disobeying them (9). This is part of Valentine's argument that women who do not uphold social norms and are raped are used as a warning for other women (385). Newspapers can serve as an unintentional form of propaganda for sexual terrorism where women are taught that certain behaviors and actions warrant sexual assault. Historically, this fear of rape has been used within social movements. For example, within the Civil Rights Movement, the fear of black men raping white women was used to hinder young white women working side by side with African Americans (Evans 44). Occupy Wall Street sexual assault coverage is part of a long history of using cases of sexual assault to stop participation in social movements. 
Part of this outlook on sexual assault stems from having the majority of power in the newsroom in the hands of elite men. Current figures from the 2013 Women's Media Center Report show that only 34.2 percent of women are in supervisory newspaper positions and overall only 36.9 percent of women have careers within newspaper companies (10). Duhram argues that having mostly elite men in charge allows for media to reflect a masculine vision of the world and what is important (3). Meyers would agree with Durman by arguing that news media contributes to the maintenance of popular consensus by perpetuating the values of the ruling elite (19). In this way, news is not constructed to challenge the status quo, but rather to support it. Since our society condones rape culture, it only seems natural that the news media would uphold the tenets of supporting male violence and placing blame on the victim. With Occupy Wall Street, it would be important for mainstream media, who have a stake in challenging economic reform to increase profit, to use the victims as a warning to women who continue to support the movement. Also, media which is privately owned has a motive for wanting the message of Occupy to be distorted, because papers such as The Wall Street Journal have direct financial ties to Wall Street. This could stop women from supporting the movement because of the fear of violence from fellow protestors. Stories of rape could also discredit the movement as violent, which could create a drop in public support.

Newspapers perpetuate victim blaming through ideas of newsworthiness, sources, language, and providing unnecessary details about the case. News coverage is then employed as a form of social control by using "bad women" as an example of what happens when women act outside their traditional gender roles, especially as it relates to public space. However, there are ways women renegotiate their traditional gender roles in 
public space, particularly as it relates to activism.

\section{Activism, Public Space, and Gender}

When women want to access public space, they must present themselves in a certain way to protect their status as good women in the eyes of the public. This is particularly true for activists who must enter the public sphere to advocate for change. This section of the literature review will use literature by Hawkesworth, West and Blumberg, and Gardner to explore how women access a male dominate space to create public and private change.

\section{Access to Public Space}

Women have historically and continue to be barred from full participation in public space. Public space is constructed for the consumption of ideas and discussion in order to promote democracy. However, Hawkesworth argues that these ideas of citizenship and democracy are centered on historically masculine traits, including the right to bear arms, the capacity to own property, and the ability for self-government (42). Women were historically not permitted to own property, or be political actors. West and Blumberg argue that women have generally been socialized to be apolitical and have been punished for ignoring gender boundaries when they venture into a masculine political sphere (4). Gardner states that women are taught through crime prevention that they should behave unremarkably in both appearance and in their activities when entering public space. By bringing little attention to themselves, women can avoid unwanted interaction from men and keep safe (24). By teaching women to silence their behavior, and creating an idea of citizenship centered on masculine ideals, women's ability to protest is increasingly difficult. Even within the Occupy Wall Street protest, men 
protesters accounted for 61 percent of protesters, and were more likely to be interviewed and photographed by the press (www.occupywallst.org).

It is also important to mention that the public/private divide of men and women fails to account for working class women and women of color who traditionally worked within the public sphere, though they did not have access to the political side of the public sphere. The ideology of the public/private divide focuses only on white upper and middle class women, which fails to account for the experiences of women of color (hooks 97). Also, according to some feminists, the boundaries of private and public have become so blurred that the public and private divide is less concrete as a concept. Staheli argues that the current dichotomy of public and private space is not useful because it ignores many of the ways women currently engage in activism (609). However, the public/private divide is still important because it still has ideological relevance and is used to stop women's full access to public space.

There have been certain times in history which women gained momentum in acquiring full citizenship by using different strategies to gain access to the political side of the public sphere (Evans; Ford; McGuire). However, while women have made some strides to accessing public space, full participation or access of public space has yet to be achieved (Gardner 17). Women must navigate how they enter public space to protest while holding on to their status as good women. This negotiation creates challenges and opportunities for women participating in activism, including within the Occupy Wall Street movement.

\section{How Women Enter Public Space}

Women activists construct a public persona similar to traditional feminine 
qualities to keep their status as good women, while attempting to challenge the status quo. Men, however, do not need to justify male participation. West and Blumberg argue that this is because men do not need an explanation to rationalize their participation, as they are seen as legitimate actors whereas women are not (22). Women are also not seen as complex individuals in public, but rather as one-dimensional characters. Gardner argues that women are reduced to one factor by men in public space such as a mother or only a beautiful woman. Differences and experiences are muted in which women are not fully dimensional individuals, but reduced to gender roles or seen as objects for male consumption (46). Rather than being seen as complex individuals, the institutions of law and media will focus on only one part of their identity. By using traditional gender roles, women can be seen as legitimate actors.

One of the most common ways of accessing public space for women is advocating for the rights of others using a mothering or caregiver role (Kurtz 417). Women work towards changing policy by advocating on behalf of their community and their families in what Naples describes as "proxy activism." In this proxy activism, women use the issues of others to meet their own practical needs (24). Krauss argues that motherhood becomes a performance in which women highlight their roles as mothers to be seen as legitimate actors in the public sphere. This performance has a dual purpose of both gaining access to the public sphere and creating a voice of authority. Women bring their experiences associated with the private sphere, such as childcare, to the public sphere. These experiences allow them to speak as experts in the form of motherhood (Krauss 101). For example, in challenging toxic waste dumps near their Louisiana community, women have used motherhood to discuss how having a waste center would 
impact their health of their children, or complicate future pregnancies (Krauss 104).

Using motherhood to access the public is a double bind according to Einwohner et al., in which using a traditional feminine role can be useful in the short term, but long term it could hurt the movement. For example, the use of emotions can help gain support for a movement, but because emotions are seen as feminine and not valued in the masculine public sphere, emotions can reduce credibility (Einwohner et al. 695). Women activists have to tread a thin line as to what is acceptable behavior in the public sphere even when they are behaving within their prescribed gender roles. Perhaps even in the longer run, these attitudes will alter masculine attitudes towards women's participation in public space, and expand the roles women are allowed to present themselves as within social movements.

\section{Repression of Women in Social Movements}

For women who fail to follow the arbitrary rules of entering public space there can be repercussions that range from silencing to threats of violence.

"As women become recognized as actors rather than passive victims, as portrayed by patriarchal institutions and ideologies, they will face increasing severe political consequences for their actions. Challenges to male dominance under certain conditions may result in the tightening rather the relaxation of control in various institutional settings" (West, and Blumberg 30).

However, violence is not the first form of repression for women in social movements. Ferree argues that women are repressed in three non-violent ways that focus on the gender roles of women. These methods include ridicule, stigma, and silencing (142). These factors are used in both individual and institutional levels to reduce the credibility of women's activism, and the women themselves. 
West and Blumberg argue that violence in social movement by law enforcement is more gender neutral, with both men and women subjected to police brutality. Evans states that within the civil rights movement women rarely expected or received any special protection in demonstrations or in jail (41). However, when sexual or physical violence is used against women during social protest, it usually arouses public sympathy and criticism. Violence against women is disapproved of, especially when it is done by law enforcement (West, and Blumberg 30). While violence can be used to keep women in their place, it is also seen as negative by the public. Gardner argues that common abuses of women entering the public sphere include exclusionary practices, exploitive practices, and evaluative practices (75). The exploitive practices work to punish women for entering the public sphere by invading personal space and limiting privacy. Kissling expands upon Gardner's work, arguing that these practices are used by men to remind women of their vulnerability and to reinforce spatial boundaries (455). While Gardner explains that these exploitive practices are seen as minor, such as pinching or taking photos of women, I would argue that women are conditioned to fear that they could lead to more serious violence as seen by the use of rape myths. West and Blumberg argue that this backlash and violence from others creates multiple areas of struggle for women, including the fight for their cause, against sexism in the movement, and sexism from the society (30).

\section{Invisibility and Marginalization}

When women participate in mass social movements, they not only face sexism from the general public, but within the movement itself. In the civil rights movement and the anti-Vietnam War protests, women were relegated to tasks that fit within their gender 
roles. Women were often secretaries and did door to door work while men took on more leadership roles and organized sit ins and marches (Evans 151). Even the rights of fellow female protesters were seen as special interests such as ending challenging sexism within the movement and being seen as legitimate members of the organization. The question of where did women's right fit within the anti-Vietnam movement was pushed aside by male leadership to focus on the "real" issues (Evans 172). Kurtz argues that this marginalization of the rights of women is because women's concerns are connected to the private sphere while men's interests are linked to the public sphere (411).

When looking at these movements from a historical lens, women activists are often invisible or their role marginalized in the movement. West and Bloomburg argue that because men have historically been in power, they decide what information is passed to the next generation, which has resulted in the invisibility of women activists. This reinforces the idea that women are apolitical (6). For example, the roles and tactics used by women in the Montgomery Bus Boycott historically have been ignored, and activists such as Rosa Parks are cast as passive characters within history books (McGuire 109). When looking at the Occupy Wall Street news coverage it will be curious to see if the women of Occupy Wall Street will be remembered for their activism or cast as victims of sexual assault, removing any agency they had in the movement.

Women involved in activism face serious challenges when creating change in the public. Women must first gain access to public space and create an identity that is politically influential, while still holding on to their good woman status. At the same time, women face repression in the movement, through non-violent and violent measures. This lack of full participation in the public sphere stems from the fear of gender based 
violence, which forces women to behave though rigid gender roles.

\section{Conclusion}

This literature review shows that blame the victim rape myths are a form of social control over women. Sexual assault news coverage creates a biased picture of violence and uses rape myths as part of the coverage. Women who access public space must do so using a certain framework to avoid violence and gain credibility. The goal of this research is to show how blame the victim myths are linked to concepts of public space. By teaching women to fear public space and the dangers within it, individual women are taught to avoid public space. This leads to a lack of participation in activism for fear of violence. Ultimately, I aim to explore how the coverage of Occupy Wall Street sexual assaults combined the use of blame the victim myths and ideas about women's participation in public space to create a discourse of women's participation in social protest. This discourse continues to promote traditional gender role ideology, where women should behave a certain way in public space. 


\section{Chapter 3: Methodology}

Stories of sexual assault cases are frequently covered in newspapers at a local and national level. Newspapers do not just inform readers about an event, but help to shape the readers' understanding of social values in our society. There are prevalent themes that support and reaffirm rape culture within the larger context of news coverage of sexual assaults. As discussed in my literature review, the use of rape myths in news coverage leads to more people supporting the perpetrator of assaults rather than the victim, and believing rape myths in their daily lives (Franiuk 298).

In the case of the Occupy Wall Street sexual assaults coverage, women's participation in the movement was linked to a narrative that included traditional forms of victim blaming found in news coverage of sexual assault as well as more covert forms. The underlying message delivered by these newspapers was women do not belong at Occupy, or in other social movements if they want to be safe from violence. As previously mentioned, the exact number of sexual assaults that occurred during the Occupy protests is unclear, but the media made it seem like sexual assaults were a common part of Occupy Wall Street. Newspaper articles can have serious consequences where the fear of rape is used to keep women from participating in social movements. By uncovering the narratives used in this case, readers can acknowledge biased news coverage occurring during social movements and create pressure on news outlets to present news stories that do not blame the victim or see women as unwelcome in mass social movements.

I am using the term "victim" to describe the women who were sexually assaulted 
rather than the term "survivor." While sexual assault advocates uses the term survivor because it is seen as more empowering, victim is used to describe the recently assaulted (Meyers 8). The newspapers covered the assaults as soon as they were aware of them, which makes the women they reported on fall into the category of victims, my choice is also political in nature. Meyers argues, the news hardly presents women who have been assaulted as survivors, but as passive victims (8). My use of the word victim is to further highlight the lack of agency given to the women of Occupy Wall Street and because it more accurately describes how the news portrays the women of Occupy Wall Street.

I use a feminist media analysis to examine the narratives surrounding the events at Occupy Wall Street. I am more interested in how the stories of the assaults were presented by the media, and how this could influence readers' perception of women in Occupy Wall Street. This question led me to choose a media analysis as my methodology. Media analysis begins under the assumption that the media functions through the repetition and support of the central ideas that are in turn accepted by the culture in which the texts are produced. Feminist media analysts then use texts to discover ideas about gender or changes in gender ideology over time (Hesse-Biber 267). Texts can highlight the taken-for-granted values that audiences receive about themselves, others, and the world around them. Media analysis helps to reveal the social contexts in which texts are produced and received (Hesse-Biber 268). This analysis of coverage of the Occupy Wall Street sexual assaults is a useful methodology to examine how ideas about women's use of public space are created and reaffirmed in the United States.

Using a feminist media analysis I explore the discourse of the coverage, and how it relates to current ideology about public space and victims of sexual assault. A discourse 
functions as a system of meanings created by a combination of texts and the social practices that inform them (Hesse-Biber 265). By analyzing texts, researchers can question meanings that otherwise go unexamined. For this project, my texts are mainstream newspaper articles that covered the sexual assaults. These articles allow me to investigate the framing of the sexual assaults and how they shaped the discourse surrounding women's participation in public space. This research demonstrates the linkages between women's participation in social movements and blame the victim narratives that could have otherwise gone unexamined by focusing on other methodologies.

Despite that coverage of the Occupy Wall Street sexual assaults spanned to blogs, social media, radio, and television coverage, I am focusing only on newspaper articles. Due to the scope of this project, I cannot look at all forms of media in the time period I have to complete the project. In addition, newspaper articles are easier to access, compared to databases on television and radio clips, which are more scattered or require additional funding (Hesse-Biber 271). In addition, I am only focusing on the sexual assault coverage in the main Occupy Wall Street camp in New York. While sexual assaults occurred in other Occupy camps around the United States, the majority of the general coverage of the movement focused primarily on the New York camp.

I collected my data through the Lexis-Nexis database, using the keywords "Occupy Wall Street" and limiting those results through the keywords "sexual assault" and/or "rape." Lexis-Nexis is primarily used by academics and includes the most popular and well-circulated papers (Hesse-Biber 270). Using this database provided me with more breadth and legitimacy compared to a Google search for news articles. From the 
articles with my keywords, I narrowed the results to include only articles from mainstream papers, defined as newspapers with a circulation of over 500,000. The sample includes papers such as The New York Times, The New York Post, Los Angeles Times, and The Washington Post (see Appendix B for a full list of newspaper articles examined). While independent and smaller newspapers also had viewpoints of the events that reached the public, mainstream papers reach a wider audience. Mainstream papers create more influence over the discourse surrounding the sexual assaults compared to smaller newspapers because mainstream papers reach more readers. To make the analysis manageable, I focused on a one-year period from the start of news coverage of the movement until the first year anniversary of the movement. I chose this as my period because the coverage of Occupy Wall Street was only heavily reported on during the first year. This length allows me to see trends as Occupy Wall Street progressed as it relates to news coverage of violence against women in the camps.

I included both news articles and opinion articles in my selection of data. While opinion articles are not represented as objective in journalism, they do have influence in the discourse of women participating in Occupy Wall Street. Opinion articles used material such as statistics and quotes from both protestors and public officials to make their arguments about the safety of Occupy Wall Street. Often news coverage and opinion articles are in conversation with each other where news articles give information about a particular event or issue through quotes and eye witness accounts, and opinion articles use that information to make an argument. Also they both use information from the same sources, such as the Associated Press. In this way, news coverage and opinion articles both presented information about Occupy to the public that contained material that could 
be considered uncontested.

Occupy Wall Street, and researchers do admit that sexual assaults occurred within Occupy Wall Street (Gitlin; www.occupywallst.org). However, apart from the newspaper coverage, there is very little detail about the individual cases of sexual assault within the camp. I relied on using the newspapers in my sample as evidence of particular sexual assault cases happening because of this lack of scholarly information. While I do argue that the mainstream media distorted the sexual assault coverage to create panic, I believe that because journalists interviewed law enforcement and survivors, that these events are reliable Critiquing these media sources does not mean that the series of event failed to occur, but rather they presented one representation of sexual assault and the meaning behind them.

I eliminated The New York Post after an initial read of the texts from the sample because its content was more tabloid-centered. While The New York Post covered the assaults in more detail than the other newspapers in the sample, the coverage was less journalistic in nature and more sensational. The newspaper presented the content in a way that was meant more to shock readers due to its tabloid nature. For example, one article from The New York Post described the reason for a women only tent as, "Zuccotti Park has become so overrun by sexual predators attacking women in the night that organizers felt compelled to set up a female-only sleeping tent yesterday to keep the sickos away" (Freund). The language in this quote is not journalistic with word choice of "sickos" and "sexual predators." Tabloidism is journalism that has titillating writing, focusing more on personality and human interest than politics or policy (Reel 138). The style of The New York Post is different compared to the other papers and would have skewed my findings 
with its over the top presentation of the events. For example another New York Post article presented this incident: “A sex fiend barged into a woman's tent and sexually assaulted her at around 6 a.m., said protesters, who chased him from the park. 'Pervert! Pervert! Get the f-k out!' said vigilante Occupiers, who never bothered to call the cops" (Jaff). It is unclear if the reporter actually saw this event take place, or is just recounting what the protesters said happened. This account uses dramatic language and sensationalism to discuss sexual assault in a way that is vastly different than other newspapers in my sample. Also, The New York Post has the lowest credibility of all New York newspapers, so while the newspaper did cover the crimes, it lacks the authority of the other newspapers in the sample (Trichter 3). I would argue that the low credibility of the paper means the content is seen more as sensationalism than factual news by readers as compared to other newspapers.

I used an iterative process of data collection in which I started the analysis of these texts without a set idea of what I would use as my focal points for the research. With an iterative process, themes emerge cyclically after reading the texts for patterns (Hesse-Biber 283). In this way, the texts guide the researcher in what is important to examine. Coding the articles for themes in this way allows me to make sure I do not miss any important information by only limiting myself to certain areas of coding. However, based on prior research from Meyers, Kitzinger and Benedict, I hypothesized that quotes from sources, language choice, and the general atmosphere of Occupy would be used to blame the victim. As my results section will indicate, the findings of my thesis presented a more complex understanding of the relationship between blame the victim narratives and the women of the Occupy Wall Street movement. 
My analysis draws upon prior feminist research on news coverage of sexual assault, especially the work of Helen Benedict in Virgin and Vamp. This book laid the groundwork for feminist research on news of coverage of rape and provided several areas to explore for themes in the coverage such as the relationship between the victim and perpetrator, and the events before the rape. I also use feminist theories of sexual terrorism and rape culture to explain how news coverage connects victim blaming with limiting women's participation in protests. Herman and Sheffield have linked sexual terrorism to print media by calling media a form of propaganda to fuel sexual terrorism (Sheffield 174). However, little research has been done relating sexual terrorism to activism. My thesis helps fill the gaps and make connections between these areas of research.

My analysis comes from a feminist framework in that it not only focuses on women's lives and experiences, but commits to finding solutions to challenge hegemonic ideologies presented in the press. Feminist research should not be done for the sake of research, but to better the lives of women. Feminist research is different than other forms of research because it is explicit in having a political stance to help to challenge social biases (Jagger ix). My thesis is not just exploring what this victim blaming towards women activists looks like, but finding solutions to help journalists create coverage that supports rather than holds the victim responsible. Likewise, my project stems from a feminist epistemology in which knowledge is understood to never be completely value free and objective. Instead, researchers have situated knowledge in which "concepts of knowledge and truth are always partial and inseparable from the lived experiences of the researched" (Hesse-Biber 5). This means as an academic, I cannot separate my experiences so they do not influence my own work. Due to this "situated knowledge," it 
is important to point out my own biases and recognize them in this project. Using selfreflexivity, I can challenge my personal biases and take steps so they did not limit my research. Self-reflexivity allows researchers to reflect on how their research is influenced by their own assumptions and social positions (Jagger 38). By maintaining awareness, I am able to acknowledge how my own lived experiences shape my work and make sure it does not hinder my analysis. While I can never be objective, I can be transparent in my investigation process.

I became interested in this project because of my background as both a Journalism and Women's Studies student. My own experiences working at the college newspaper at Iowa State University led me to question how reporters cover some stories and my own experiences covering the police beat for one summer. After witnessing biased coverage on high school gang rapes and opinion articles arguing for women to drink less to avoid being raped, I became curious in how new coverage frames sexual assault. Once I learned about the Occupy Wall Street sexual assaults, I was interested to see how these issues played out under the wider framing of Occupy Wall Street, which was viewed by much of the mainstream media to be disorganized and comprised of unsavory characters (Deluca, Lawson, and Sun 491).

Going into the project, I understood that my own biases would shape my work. I struggled with my own opinions of Occupy Wall Street and how they would influence my research. I was a supporter of the movement and took part in my local Occupy movement. However, I became disheartened and concerned when I heard about the increasing violence against women protestors occurring in the camp and other problems within the "leadership" of the movement where women of color's voices were silenced. I 
believe that Occupy sparked a conversation on economic inequality, but members of the movement were not as progressive as they claimed to be.

Also, as a woman and a strong advocate for survivors of sexual assault, I understand that this research will be influenced by my experiences. I have not been immune to the fear that the danger lurks out in dark alleyways, or in the bushes. While my literature review and my own experiences show that sexual assault is much more likely to happen in the home than on the street, I still struggle with fear when out at night in certain areas. While I have not participated in any movement as large as Occupy Wall Street in New York City, I do wonder if I would feel safe there, after seeing the coverage of the movement. I pondered whether my knowledge of sexual assault and crime would be enough to allow me to feel safe camping in a public space with strangers while knowing the police might not help me if something happened. These experiences are not limitations, but the fuel that drove me to investigating the coverage of Occupy Wall Street.

That being said, there are some limitations in this research. Media analysis does not present all framings of a text; there could be other interpretations that could present themselves to readers. As Hermes states "textual analysis can never be taken to predict or explain how audiences will read, experience or interpret a text" (156). Nonetheless, this research provides one interpretation that can help to understand the struggles of women who participate in social movements and how the fear of rape limits women's political participation. In addition, because I am only focusing on mainstream coverage, I am not including the responses through online commenters, and blog posts that challenge the coverage of the events. This research also does not account for women's stories or their 
own experiences in Occupy Wall Street that could contradict how the news covered their participation. Future research should look at how these events were discussed in other places or focus on how sexual coverage was covered in other social movements. Using a feminist methodology, I explore the discourse surrounding these events with a media analysis to better understand the different ways blame the victim myths are used. With this knowledge, the results of this research should be used to help journalists create coverage of social movements that is both fair to the participants and to the survivors of sexual violence..News coverage strives to be objective in presenting an issue or event. Journalists would benefit from this change in coverage because it would give more credibility to their work and present a less subjective presentation of news events. 


\section{Chapter 4: Analysis of Data}

The fascination of news outlets with Occupy Wall Street expanded well beyond what perceived to be the bizarre tactics of the protest. Articles discussed the daily life of the protesters, why economic inequality was worth protesting, and crime within the camp. As Occupy grew as a movement, so did the news coverage focus on the deviance of the protesters. While coverage of the protests was predominately negative from the start, the spotlight on crime became more detailed in October and November's coverage and the news fixated on the numerous sexual assaults occurring within the camp. Sexual assault seemed to be a daily problem within the camp with quotes like: "Zuccotti Park has become so overrun by sexual predators attacking women in the night that organizers felt compelled to set up a female-only sleeping tent to keep the sickos away" (Taranto “Obamaville Riots"). Negative coverage of Occupy included detailed reports of violence, which led me to several questions. What did this coverage mean for the survivors of sexual assaults in the camp? Were the victims blamed for being in a place that the press vilified?

My original assumption was that Occupy Wall Street would have easily identifiable examples of victim blaming, which is typical of sexual assault case coverage. I expected source quotes used to discredit the victim, the relationship between the victim and the aggressor would be scrutinized, and details would be used to paint an unflattering view of the victim. After my analysis, I found a more complex and intriguing understanding of how sexual assault coverage functions within social movements. While more blatant forms of victim blaming continued to be found in the news coverage, more 
notable was a covert form that was rooted in the negative perception of Occupy Wall Street in the press. This blaming the victim narrative helped to stop women from participating as activists. I argue in this thesis that the discourse that emerged within these articles shows that not only would women be assaulted if they participated in Occupy Wall Street, but that those outside the movement would see it as their fault. This discourse was shaped through two types of coverage of sexual assault occurring during Occupy Wall Street, indirect and direct.

\section{Direct and Indirect Coverage of Sexual Assault}

Before focusing on the content of the newspaper articles, it is important to discuss how news coverage of the Occupy Wall Street sexual assaults fell into two different categories that I call direct and indirect coverage. Direct coverage styles itself after traditional sexual assault reporting by providing an overview of the case, details of what happened, and who was involved. Within this category, three major cases were reported on by multiple papers and will be discussed in my analysis of the coverage.

While these three cases will be discussed in length in my analysis, this is a brief summary of the reported cases of sexual assault by the news media. While scholars such as Gitlin have discussed the sexual assaults that occurred in the camp, they provide little

detail about the sexual assaults other than mentioning they happened. Occupy Wall Street does not have a record of the sexual assault cases, so I am using the newspaper coverage as evidence that these particular sexual assault cases occurred, though they may have disorted by the press.

The first sexual assault case was reported on in November 2011 by New York Daily News, The Wall Street Journal and The New York Times, where Tony Iketubosin, 
an Occupy protestor who worked in the kitchen, was charged with sexually assaulting two women on two separate occasions. Also in November, was the second case of Lauren DiGioia, who was sexually assaulted her first night in the camp, and reported her assault to the police. This case was reported by The Wall Street Journal and New York Daily News. The third case occurred at the one-year anniversary of the movement when Jackie Barcliff sexually assaulted a 56-year-old woman before throwing her off a second story railing. This case was primarily covered by New York Daily News and The New York Times. Within the coverage of these three cases, newspapers continued to show typical forms of victim blaming that mirrored other non-protests sexual assaults such as commenting on drug usage of the victim, and questioning the victims' behavior prior to the assault.

Indirect coverage did not focus on the individual crimes themselves, but how sexual assault fit into the larger context of violence at Occupy Wall Street. These articles mention sexual assaults happening within the camps, but did not provide details of the crime. This type of coverage connected sexual assault with other crimes in the camps and the general atmosphere of Occupy. The main areas these articles focused on included how Occupy internally dealt with crimes, tension between police officers and the protesters, and Mayor Michael Bloomberg’s frustration with the protest.

In this indirect coverage, the women of Occupy Wall Street are rendered invisible. Women are not mentioned as protestors, but strictly as victims with no voice. Others, usually men in the movement or men in power, such as police officers, speak for them. No details or context are given to the sexual assaults, rather, violence against women is linked to other forms of violence happening during the occupation of Zuccotti 
Park. This type of news coverage focused more on the violent nature of Occupy Wall Street itself rather than the details of sexual assault in the camp.

Indirect coverage did not have the conventional victim blaming as did articles on individual cases of assault. Instead, this type of coverage uses more covert forms of victim blaming, where patterns emerged within the coverage that blame the victim, even without mentioning direct cases of sexual assault. My analysis focuses on how these patterns become forms of victim blaming. These three themes I have entitled: "Guilty by Association," "No Place for Women," and "On Your Own." While these themes occur more readily in indirect coverage, they can be found weaved into the direct coverage of sexual assault at Occupy Wall Street and are often used in relationship to traditional victim blaming.

\section{Guilty by Association}

Despite the sheer number of people involved in the protest, the coverage of Occupy Wall Street presented the activists as a fringe group working outside the needs and experiences of normal Americans. The individuals in the movement were constantly othered from mainstream society through coverage focusing on the protesters' political views and ways of invoking change. I argue in this section that by othering the protesters, news coverage presented the men of Occupy as deviant men and whom posed a threat to others and that women should avoid. This theme centers on the presentation of the protesters as dangerous individuals who used violence as their main tactic in the movement.

Newspaper coverage suggested that women who associated with these dangerous individuals should have known better and therefore the potential for sexual assault was an 
“occupational hazard." For example, The Los Angeles Times interviewed someone outside the movement and stated the following, "'In real life, there is poverty and homeless people and there's crime,' Gautney said, citing issues that in recent weeks have arisen in Occupy camps, where rapes and theft have been reported" (Popper, Baum, and Susman A1). By linking homelessness and crime with sexual assault, this sentence implies that because "real life" or public space has dangerous people, sexual assault is bound to occur.

This is linked to the myth that certain people are more likely to be rapists and are somehow different from other men (Lonsway, and Fitzgerald 142). Often sexual assault is seen as something that only strangers or criminals do, rather than acknowledging the fact that most sexual assaults are committed by someone the victim knows. By feeding into the myth that only deviant, treacherous men rape, representations in news media suggested that women should have expected this behavior from the men in the movement. The coverage suggested women as putting themselves at risk by surrounding themselves with men who were associated with deviance.

\section{Presenting the Men of Occupy as Dangerous}

While some two newspapers articles viewed the protesters as aging, anti-Vietnam War activists or millennials angry at the world, the majority of the coverage from The Wall Street Journal, The New York Times and The Washington Post, presented members of Occupy Wall Street as violent and dangerous. Describing the protesters in unflattering ways allowed people outside of Occupy Wall Street to ignore the purpose of the movement - economic inequality - because the group was too radical. Marking protesters as deviant is common in coverage of activism. Because activists are often challenging the 
status quo, they are seen as unruly disturbers of the established order (DeLuca, Lawson, and Sun 491). Stereotyping the protesters in this way does have implications for how the narratives of the sexual assault victims are discussed. By associating with the protesters, women in the movement were cast as amoral, which lead others to blame them for their sexual assault.

Articles acknowledged the diversity of different social groups in the protest, but the framing of the coverage focused on the most dangerous factions. The articles suggested that while at first glance, the movement seemed like a disorganized hippie group, the truth was that it was much more sinister and dangerous. For example, one article describes Occupy Wall Street as "like the Boy Scouts teaming up with the Hell's Angels" (Knight B3). In order to mark the protesters as perilous, newspaper coverage focused on literary metaphors and animal analogies to describe the members of Occupy Wall Street. "On its tie-dyed surface, the OWS movement seems little more than a confused collection of grievances" was one article's opening representation of the protests (Gerson A17). The same article then discusses the violent tactics of the activists

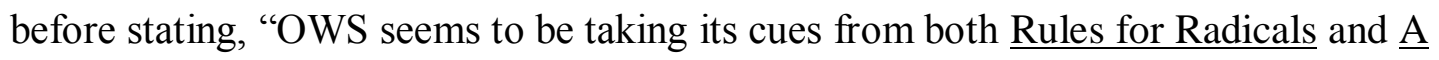
Clockwork Orange" (Gerson A17). The plot of A Clockwork Orange revolves around a group of teenagers committing senseless acts of violence for pleasure, included the rape of two ten-year old girls and an elderly woman. In the climax of the book, the protagonist ends his deviant ways after the government experiments on him and takes away his ability to commit violence. By using this book to describe the protesters, the men of Occupy were cast as not only dangerous, but enjoying the violence they were committing, including sexual assault. This comparison also suggests that government is 
responsible for ending the violence because the protesters, like the protagonist in $\underline{\mathrm{A}}$ Clockwork Orange, will not end it on their own.

Another opinion article from The Wall Street Journal, uses similar language by admitting that the protesters were not inherently violent, but the nature of Occupy Wall Street created violence. "We [the reporters] found it populated by innocent and wellintentioned, if not confused, young people. Then again, that's how Lord of the Flies began" (Taranto, "Obamville Riots"). While this quote brings some humanity to the protesters by calling them "well intentioned," the majority of the article focuses on the Lord of the Flies-esque behavior of the protesters. Like A Clockwork Orange, the plot of Lord of the Flies revolves around a group of boys trying to govern themselves, this time on a deserted island. The boys are unable to act civilly, and instead fought amongst themselves for power. This results in chaos, including animalistic behavior and the death of some of the children. Again, this comparison shows the protesters as uncivilized, animalistic, and prone to violence.

These analogies to the novels are also telling because it shows how the protesters were supposedly behaving. The references to $\underline{\text { A Clockwork Orange and Lord of the Flies }}$ are similar in that both books focus on an unsupervised group of boys and men creating havoc and following their own code of behavior. These unflattering remarks were used to present the protesters in a negative light, as well as present the protests as primarily masculine. By mentioning the analogies that feature a main cast of only boys, women are ignored as activists, which render them invisible. Women's contributions are not discussed, unless it is about their own safety. Female activists are primarily mentioned as victims of male violence within Occupy Wall Street and used as an example of what 
happens to women when they enter a dangerous and masculine space.

One example of how working with these men was presented as dangerous was the Barcliff sexual assault case. Barcliff, a volunteer for Occupy, was presented as a hardened criminal, with newspapers mentioning that he served time for selling drugs, attempted robbery and was a serial parole violator (Jacobs). Coverage from The New York Daily News focused on the Occupy Wall Street connection, even though the sexual assault happened at Pier 15 Park, not Zuccotti. Newspapers mentioned how the victim met and knew Barcliff from Occupy Wall Street demonstrations (Newman; Jacobs). Little detail is given about the crime or the victim, other than how the two individuals knew each other. More attention is paid to Barcliff's criminal exploits as well as being a "known presence at the protest" (Newman). This coverage suggests that members of Occupy Wall Street have criminal tendencies. Presenting Barcliff as not only a criminal, but also a member of Occupy Wall Street was seen as relevant information to the case. In this way, the coverage makes the connection that if the victim had never gone to Occupy, she would have never met the man who assaulted her.

It is also important to note that women are taught to avoid strange men, or men thought to be dangerous, as a form of protection. Since the dominant stereotype of a sexual predator in public is that of a violent strange, this image creates the myth that only bad, violent men are capable of assault. Women can simply avoid these men to avoid rape (Stanko 153). By marking Occupy Wall Street protesters as dangerous and violent, they would be seen as individuals that women should shun. In this way, women "should have known better" and were blamed for disregarding warnings and placing themselves in a violent situation. 
Occupy Wall Street featured a variety of different political and ideological groups with many complex reasons as to why they were involved in the movement and how they wished to accomplish their goals. However, over half the news articles in the sample focused largely on the extreme counterparts of the protests and their violent tendencies. This presented the protests as dangerous and made up of aggressive individuals. One way the articles presented the protesters as appalling individuals was by focusing on the political groups within Occupy Wall Street. "It [Occupy Wall Street] garners support from such illustrious groups as the Communist Party USA, American Nazi party, Socialist Party USA, Marxist Student Union, Black Panthers and the white supremacist group White Revolution" (Milton B1). Constructing a list of groups that each have negative connotations in the United States creates the idea that the people involved in the movement all shared the same beliefs or perspectives. Also, by conflating these groups together it makes them seem equally notorious. It removes the context of these groups' creations and removes the differences between groups, such as the white supremacists and the Black Panthers.

News articles from The Wall Street Journal, The Washington Times, and The Washington Post linked Occupy Wall Street to socialist and anarchist groups in particular (Corvitz; Gerson A17; Knight B3). Socialism and anarchism are words in American rhetoric that still have negative connotations, and supporters are seen as inherently antiAmerican. For example The Washington Times reported, "They [socialism and anarchy] share a belief that the capitalist system is a form of 'institutionalized violence' and that normal, democratic political methods are inadequate. Direct action is necessary to provoke the crisis that ignites the struggle that achieves the revolution" (Gearson A17). 
The article next mentions acts of violence from protesters, including setting fires, and rock throwing. This article suggests that these will use violence as a means to overthrow capitalism. By highlighting the most extreme groups, the way the media presented Occupy Wall Street went from that of a protest focusing on economic reform to being a violent, anti-capitalistic movement.

\section{The Behavior of Bad Men}

News coverage linked the idea that men in the protests were dangerous with the violence in the movement. (Corvitz; Gerson A17; Knight B3; Taranto). As coverage of Occupy Wall Street progressed, the articles changed from focusing on the lack of the goals of the activists, to the violence in the camps and violence against opposition to the movement. As one opinion article from The Wall Street Journal explained, "It is certainly true that the so-called protester are 'not merely yelling and screaming.' They're also engaging in a fair bit of physical violence as well” (Taranto, “Obamaville Riots").

News reports described the protesters as prone to fits of violence when they did not get their way (Corvitz; Gerson A17; Kengor; Knight B3; Taranto "Better Late Than Never"; Taranto “Anarchy Looks Like”).One news article mentioned that once a food cart refused to donate free food, owners found their cart smeared in blood and urine and started to receive death threats (Taranto, “Anarchy Looks Like”). The Wall Street Journal noted that another protester "ripped out a credit card reader from a counter and threw it at workers" when McDonald's refused to give him free food (Taranto, "The Obamaville Riots"). These acts of violence were not just directed outside of the camp, but also between individual protesters. One EMT interviewed in The Wall Street Journal stated she was called to Occupy fourteen times because of physical assaults between protesters 
(Taranto, "Anarchy Looks Like"). Yelling matches often erupted into fits of violence. (Buckley, and Flegenheimer A24). Newspapers focused on the violence of the movement and how dangerous it was becoming.

Violence became associated with normal behavior with Occupy, and reporters argued that it was not being taken seriously by Occupy supporters. In another article from The Wall Street Journal, the reporter said, "Many of our urban leaders have persuaded themselves that the drugs, sexual assault and vandalism that accompanied the Occupy movement are all 'isolated incidents." (MacGurn). The coverage displayed showed that by allowing these instances of violence to continue, the protests would only become more dangerous. MacGurn's opinion piece argued that Occupy was an example of the "broken window theory," in which minor acts of deviance within Occupy would only cause more severe forms of violence to occur more regularly. Another paper argued that allowing violence as a solution would create riots. "Once the enraged masses spill into the streets in more cities, the chances for violence grows exponentially. Class envy and hatred engender an unhealthy rage, and the desperation of the times amplifies the danger" (Kengor A11). Occupy was presented as a violent movement which only become worse as time progressed. By allowing petty crime to occur, sexual assault and more serious crimes were seen as more likely to occur.

Sexual violence was often used as an example of the increasing violence occurring within the camp. The presentation of this violence did not mention the victims themselves, but blame was attributed to them by the mere fact that they continued to engage in a social protest that allowed violence to occur. One article from The Washington Times twisted a quote from President Obama about financial bankers to 
apply the Occupy Wall Street. "People who are irresponsible, who are reckless, who don't feel a sense of obligation to their communities should not be rewarded" (The Washington Times B2). This quote appeared after discussing the violence in the park, including sexual violence. While this quote was not directed at the sexual assault victims and at the movement as a whole, the protesters are presented as deserving what happens to them by allowing this behavior to occur. The Wall Street Journal shared a similar mentality stating, "When the crazies come for you, you're on your own" (McGurn). These quotes highlight that by associating with Occupy Wall Street, one must deal with the consequences, since it was self-chosen.

Sexual assault victims placed themselves at risk by interacting with men who behaved violently. Victims and Occupy Wall Street protesters who allowed smaller acts of violence to occur, encouraged more dangerous acts to manifest. Victims assumed the risk by associating with men who were presented as becoming increasingly more violent. Women were cast as foolish for continuing to stay in a setting that allowed violence to occur and allowed criminals to volunteer to help the movement. For example after the set up of a safe house tent for women, The New York Daily interviewed a woman who stated, "Certainly women are the first target for any type of crazies, but I live in Park Slope and the rapists there are more scary" (Schapiro, Karolizsn, and Wills 5). The protester could be read as foolish for admitting that violence against women is happening in the camp and despite this violence she continues to stay in the movement. If the people involved in keeping Occupy Wall Street going were committing acts of violence against their fellow protesters, it would make sense to stay away. For the women in Occupy, their co-workers and volunteers of the movement could not be trusted because they were prone to violence 
against others, even sexual assault.

At the same time, the news coverage from The Wall Street Journal, New York Times and The Washington Times presented stereotypes that anarchists, gang members and ex-cons are not "good" men, and women should have kept away from the protest. For example a Washington Times opinion article begins with a bulleted list of events at Occupy Wall Street with the following phrases, "Signs suggesting violence against authorities and businessmen. Endorsements from both the Nazi Party and The Communist Party. Reports of sexual assaults on teenage girls (Knight B3). This list makes the connection that supporters of violent groups were in the same movement with those who would sexually assault. These men could be seen as capable of committing forms of violence against women within the camp.

The victims were blamed for participating in demonstrations were violent both internally and externally. Reports suggested that it was only a matter of time before the violence was turned on to women in the movement. By associating with men who had criminal records and were anti-American, women were blamed for the violence committed against them because they put themselves in harm's way. Danger was more than just the men of the movement, but also the physical space where Occupy Wall Street took place.

\section{No Place for Women}

Despite the fact that Zuccotti Park is actually on the wealthier side of New York City, the newspapers used Occupy to create an image of a dirty, lawless, crime-ridden area (Crovitz; Grossman, and Firger A21; Saslow, and Lynch A1; Taranto, "The Obamaville Riots"). This presentation is similar to descriptions of neighborhood 
degeneration and made it seem as though violence was bound to happen. Representations in the media suggested that the park transformed from a safe place for women to a dangerous zone. Articles presented an image of Occupy where the physical space of the camp was somewhere that women are not welcome. This theme used language and imagery that linked the camp in Zuccotti Park to a dangerous seedy part of town by focusing on the uncleanliness of the space, the physical set up of the camp, and discussions of the tents themselves as public space. Occupy as a place unacceptable for women to enter allowed for blame to be placed on the victims of sexual assault by stating that they should have known better than to enter the space. This centers on the idea that there are places that unfit for women to venture into if they are good women because these areas are seen as more likely that a rape will happen.

\section{Focus on the Obscene}

One of the central aspects of the Occupy Wall Street movement was the literal occupation of Zuccotti Park. The park as an outdoor area was not meant to accommodate the protestors as living quarters. Occupy ran into problems supporting the people's needs as more individuals started to join the protests; this included bathroom access and running water (Grossman, and Pervaiz A21). Newspapers seemed fixated on the uncleanliness of the park due to the protestors. As The Washington Post aptly put it, "is this an occupation or an infestation?" (Saslow, and Lynch A1). Often ominous phrases including "sanitation hazard" and "intolerable health and safety concerns" (Taranto, "The Obamaville Riots") were used to explain how bad these spaces were. The general message was that these spaces were no longer safe for occupation and were a threat to an individual's health. Descriptions of the living space of protesters used words such as 
"filthy," "dirty," and "squalor," - all words that do not have positive connotations in our society. The articles put blame on the protesters for the grotesque nature of the park because they were not behaving like normal individuals.

The press had a horrified fascination with the bodily functions of the protestors. Tasks that are typically seen as private were now the focus of news coverage. Frequently articles would mention that sex acts and bathroom functions were performed in view of others (Knight B3), as well as public urination, (Gerson A17) and masturbation (Wolf B1). By mentioning these instances, the protesters were cast as less than human for not following the social norms of behaving in public. This caused serious problems for women in particular because "good" women are not supposed to discuss bodily functions, let alone perform them in public. The female body is marked as taboo because of its reproductive capabilities. In order to have a civilized body, women must conform to these taboos and laws. Monitoring bodies becomes a form of social control, in which women are trained to regulate the body to fit the proper standard of femininity (Bordo 91). By acknowledging their bodies and attending their needs in public, the bodies of these women became uncivilized, meaning they moved from good women, to uncivilized women. Even if they were not urinating in public, they were still contaminated. As the scholar Eldridge explains, "Whilst it is a temporary act where the evidence and perpetrator may quickly disappear, urine and urinators, when understood as 'disgusting,' prompt a chain of associations whereby other bodies and objects in discursive or physical proximity may be contaminated" (41). What this means is the act of public urination is more than just the action, but linked to the space and people themselves. By having women engaging in these conditions at Occupy Wall Street, sexual assault cases were to 
be seen as the woman's fault because she was already in a space with lewd behaviors taking place and her prior behavior was seen as questionable.

The squalid living conditions of the protesters were often linked to instances of sexual assault, as if the dirty living space naturally meant that violence against women was more likely to occur. Often this report of sexual assault would not feature a particular case, but just mention that it was happening. Usually this connection between dirty space and violence against women was presented through a laundry list of problems at the camps. For example, an editorial by The Washington Times explained the current state of Occupy Wall Street by referencing the following problems, "sanitation, food, health issues, petty crimes, drug use, sexual assault, fights and free riders" (B2). The Wall Street Journal mentioned the movement "features rapes, drug use, and public health dangers" (Crovitz). By phrasing the problems of Occupy in this way it makes the connection that if these unhealthy living conditions continued, more violence certainly would occur. Listing these problems in this way makes the argument that these issues are logically connected. Unclean living spaces are cast as not only a public health danger, but also as a precursor to more sexual assault cases. In this way, dirty spaces reflect out of control, marginal people who are more likely to commit crime. Protestors noticed this association between uncleanliness and violence and argued it was another way to discredit the activists. One protestor commented, "First it was unsanitary, now they say it's unsafe" (Schapiro, Einhorn, and Kennedy 5). Protesters themselves recognized the discourse that the newspapers were trying to present. While individuals in Occupy Wall Street tried to argue that the movement was safe, the press, who already presented it as dangerous and dirty, made it hard for protesters to counter. 
The women already participating in the protests were seen as unclean, and this marked them as more likely to engage in behavior outside of traditional gender roles. Sexual assault victims, who are seen as "unclean" are blamed for their rape because they are already associated with impure behavior. Readers received the message that women who allowed themselves to be in this space ran the risk of being sexual assaulted. Sexual assault victims, therefore, should have known better..

\section{Tent Cities}

This concept of physical spaces unfit for women was also used by relating the physical space of Occupy to a slum-esque neighborhood. Descriptions of the Occupy camps by news coverage made it seem like Occupy was its own city within a city in the heart of New York. "They operate like miniature societies, with their own chefs, libraries, medical facilities and daily newspapers" (Saslow, and Lynch A1). While Occupy did have their own amenities, the descriptions used to describe the park centered on it being a lawless, run-down, crime ridden area. For example The Wall Street Journal stated, "Local residents and business men have grown weary of the health and safety violations, drum circles late into the night, and trashing of shops and restaurants (Crovitz), The Washington Post reported, "recent news updates from Occupy protests read like a crime blotter" (Saslow and Lynch A1). This imagery focused on the tensions between subgroups of Occupy and the petty crime occurring in the camp. Often this was linked to the sanitation and health issues that were occurring in the park and mentions of sexual assault. By placing imagery of a crumbling city, the news coverage presented Occupy as a seedy and dangerous place to be. This imagery used analogies that women in particular would associate with places that they should not venture into, and mentions of crime 
occurring in the camp.

One of the problems with the growing movement was the constant need for more space in a restricted amount of land for protestors. While The New York Times stated that there were "agreed upon paths through the park," they were becoming increasingly crowded. One report mentions that "nearly every patch of cold, hard ground in the park is a sleeping space, work space, kitchen or library" (Grossman, and Pervaiz A21). This packed area of tents made it harder to police the camp, as it was impossible to see every nook and cranny within. Members of Occupy mentioned that the swell of new tents made it harder to monitor the park. As one article described it, "tents have popped up transforming the open park into a beehive of private hidden spaces" (Buckley, and Flegenheimer A24). Mentioning that the increasingly crowded park was creating hidden spaces suggests that danger could be lurking in these spaces. Women are taught to stay on guard in these spaces because they can easily conceal an attacker (Valentine 387). Women are pressured to always be on the lookout for danger in public places to protect themselves from assault. By entering a dangerous place, Occupy Wall Street protestors might be "asking for it" by failing to practice safety techniques. Coverage of the increasingly crowded spaces mentioned the growth of crime within the camp. By providing examples of crime, the message given was that Occupy had become too large to police.

As more and more protestors flocked to Occupy Wall Street with their tents and tarps, media coverage focused on the various sub-groups in the movement staking out their place in the space. Often they described the tensions between these groups using euphemisms that likened the friction to gang violence: "The congestion has led protest 
factions to stake out their own neighborhoods and cut their own deals" (Grossman, and Pervaiz A21). Each sub-group of Occupy had their own area within the camp, creating subsections of the park. A report from The New York Times stated that the park had divided into neighborhoods, with the western edge along Church Street as "the wrong side of the tracks" (Buckley, and Flegenheimer A24). Even within Occupy, there were areas that were seen as bad places to be by the protesters themselves. This focus on tension within the camp and linking to gang violence made it seem like another bad area where women should not venture. Gang symbolisms were also present in the behavior of the protesters. Often mentioned was drug use in the camp, with articles mentioning drug overdoses and "hypodermic needles everywhere" (Knight B3; Saslow, and Lynch A1; Buckley, and Flegenheimer A24). Papers also stated that vandalism and graffiti was appearing in the Zuccotti Park and areas surrounding the park (McGurn; Taranto 4). Graffiti is often presented as a way of marking gang territory and has connotations of dangerous areas in the United States.

Gang membership in the United States is stereotyped racially with the majority of members are thought to be Latino or African American. White members are ignored (Esbensen, Finn-Aage, et al). This is intriguing considering Occupy Wall Street was predominately a white movement, (Occupywallst.org) but the participants were compared to racial subgroups. By delegitimizing the whiteness of Occupy Wall Street, newspapers made the protests appear more dangerous and less respectable in the eyes of those outside the movement. This created the appearance that the activists had less of a right to protest. Another image constructed to portray Occupy was that of a shantytown or 
condemned building. Often the protesters were described as squatters or "the professional homeless," which means the places they live are described as being dangerous as well (The Washington Times B1). At the same time Occupy Wall Street had an increasing homelessness problem, with homeless individual using the space of Occupy as a place to squat. The New York Times referred to this problem as "the same laws that allowed dedicated protesters to sleep in Zuccotti Park also allowed freeloaders" (Grossman and Firger A21). One Washington Times article stated that "street people were being confused with activists" (Knight B3). Often protesters would blame sexual assault on the homeless, rather than the Occupiers. For example one protester stated, "This is not a shelter or soup kitchen. We can't be a haven for rape and assault" (Grossman and Firger A21). Linking the assaults to homelessness supports the myth that certain populations are unsafe and where women are more likely to be assaulted.

These examples of drug use and homelessness are problems associated more with urban areas, and urban areas are frequently presented as dangerous for women. "Women make judgments about their safety from preconceived images about that area and its occupants, as well as from cues about social behavior from the actual physical surroundings. For example signs of incivility such as vandalism and graffiti suggest inappropriate or threatening behavior is possible or permitted" (Valentine 387). By seeing these forms of illegal activities, women could believe that more forms of violence would occur within the area. This type of behavior is not associated with well-respected communities, and represents neighborhoods that do not have a good camaraderie with government services such as law enforcement, sanitation, and public works.

These actions demonstrates that Occupy Wall Street, while considered a miniature 
society within a city, was not functioning as a community should. It was presented as a broken, struggling area with frictions between protesters and squalid living behavior. Linking their actions to racial and class stereotypes, allows for the movement to be discredited. Portraying Occupy Wall Street in this way meant that violence could be blamed on a certain group rather than focused on the larger context of violence against women. For sexual assault victims, the assault was their fault for willingly putting themselves in harm's way. Living in an area where there is rampant drug use, and tensions between groups and crime meant that women should expect that they could be victims of a crime. This was further exemplified by the fact that there was nowhere in Occupy for women to escape from public space, not even their own tents.

\section{Private Tents Become Public}

Another way Occupy Wall Street was presented as a place not for women was the issue of privacy. While tents are usually considered a way to have privacy in a public space, the tents were beginning to become public spaces rather than individual dwellings. In November of 2011, there were over 200 tents within Zuccotti Park and they had anywhere from one to 30 people within a tent (Grossman, and Shallwani A21). The growth of Occupy meant that more room was needed for the increase in protestors. Smaller tents made way for larger, more military style tents, complete with bunk beds that could fit larger groups of people. Often this meant that strangers were rooming together, or with friends made within the movement.

Protestors were wary of the move to larger tents, citing that they preferred the privacy of individual dwellings. One protestor stated in a New York Times article, "I think it is going to take away people's personal space and that will exacerbate the already rising level of 
tension" (Grossman, and Shallwani A21). Rooming with strangers would intensify problems between protestors, and living with strangers could cause more crime to occur, as when private spaces become public there is little control over what happens in the space. Another New York Times article stated, "The emergence of a criminal element has become a thorny challenge for Occupy Wall Street as it has transformed from an open-air encampment with little privacy to a tent city" (Grossman, and Figer A21). As Occupy became larger, the sense of privacy decreased, which this article states created more violence in the park.

Women in particular might be wary of rooming with strangers because they are socialized to be suspicious of unknown individuals. When women are in public, encountering any stranger is potentially unpredictable and uncontrollable, which means women's interaction and communication with others profoundly affects their sense of security in public (Valentine 386). Willingly rooming with these individuals is a form of putting themselves in harm's way. The news heightened this fear by focusing on the assaults that occurred within these tents, citing that these were no longer private spaces for women. (Buckley, and Flegenheimer A24). Law enforcement noticed the fact that illegal activities were happening in the tents and required Occupy to keep one tent flap open so police could check for illegal activities. However, the same reports mention that it has not stopped crime from occurring, including sexual assault (Gowen A1).

One example of this was Tony Iketubosin sexually assaulting two women within the tents. The first sexual assault happened when he and the victim shared a tent after the victim had an argument with an individual she originally has shared a tent with. She went to bed in Iketubosin's tent and woke up to him removing her pants and then raping her. 
The second sexual assault committed by Iketubosin occurred after he helped the victim set up her tent and she found him in her tent the next day and refused to leave. He then assaulted her until she pushed him away (Grossman, and Fardiner A21). Iketubosin preyed on the women via the tents, but he was not the only one. Laura DiGioia also had a man in her tent who "groped" her and attempted to rape her (Schapiro, Einhorn, and Kennedy 5). In all of these cases, the tents were the site of the sexual assault and occurred when the tent became a public place rather than a private space . Both in and out of the tents, women had no place in Occupy where they could feel safe. The press presented the women's place of sleep and privacy as filled with strange individuals who could harm them. This is important because women are taught that strangers are the thing to fear, and by sleeping within the same vicinity of these strangers puts them at risk for danger.

The coverage of women who were sexually assaulted was similar to the coverage of traditional news cased of individual instances of sexual assault. Newspapers alluded to the foolishness of the victims for sharing a tent with strangers in the first place, such as the first victim of Iketubosin. One New York Times article mentioned that after a fight with a friend, the victim "met Iketubosin. He offered to let her stay in his tent. The alleged victim took Iketubosin up on his offer" (Grossman, and FirgerA21). This quote points out that Iketubosin is a stranger to this woman, and yet she still decides to sleep in his tent. This allows the blame to be placed on the woman for sharing a private quarters with a strange man (or several men).

In a Washington Post article focusing on the "casual" hook-up culture of the Occupy camp describes the sexual activities of the members of the movement, including 
"cuddle puddles" where random protesters fell asleep in groups, and sexual activity occurred in the tents (Gowen A1). This article presented the women of Occupy as highly sexually active by linking them to promiscuity and sexual activity in the tents. The tents were seen as a space where sex was happening, and also a place where strangers were living together. The same article mentions how sexual assault also occurred in the tents. "More than 50 arrests have been made for various offences since October, including charges of sexual assault" (Gowen A1). Rape myths would suggest that when a woman shares a tent with a strange man, she knows the risks and does it anyway or welcomes the man's behavior. By sleeping in a public area, rape myths teach that women should expect this behavior to happen, leading others to blame them for their sexual assault.

The descriptions of Occupy Wall Street made it clear that this was not the place for women to spend time in, let alone spend the night. Occupy was a filthy dirty place in which individuals were acting like animals, not like decent humans. The camps were crowded and slum- like with frequent drug use and violence. There was no escape from other protesters as sleeping arrangements were with others, and often with strangers. Sexual assault was something that was just bound to happen in a place like that. Women should have known better and thus deserved their assaults for allowing themselves to be a part of a movement that allowed this type of living conditions to occur. Not only was the physical space of Occupy a problem for women to overcome, but also the lack of support from their fellow protesters and law enforcement.

\section{On Your Own}

Interlaced through the coverage of Occupy Wall Street violence was a sense of lawlessness, with police and protesters constantly at odds with each other. Both sides 
blamed each other for not adequately responding to the various forms of violence occurring within the camp, including sexual assault. This portion of my thesis explores how the media coverage of sexual assault reveals that women in Occupy Wall Street were on their own in regards to their safety and well-being. I argue that women received the message that lacked protection from violence. News coverage showed law enforcement as unwilling to be involved and protestors failing to hold criminals responsible for their actions. This message was articulated through news articles commenting on Occupy's method of de-escalation, protestors believing police failed to take crimes seriously within the camp, and a focus on risk reduction for women protesters. Women received the message they would have little to no protection from a constant news stream of coverage that questioned the safety of the camps and reports of continuing sexual assaults.

This falls into the myth that if a woman wants to be safe and protected, she needs to be accompanied by a man (Madriz 16). Without men's watchful eyes, it is up to women to protect themselves, and therefore they are responsible if they fail to stop violence from occurring. Even though women are taught to fear men, men are paradoxically seen as women's "ultimate saviors" (Madriz 16). This is true in the case of Occupy Wall Street, where women were supposed to be wary of their fellow men protesters, while also looking to them for protection. Women in Occupy were blamed because they ventured into an area without the protection of men, which caused them to be unsafe and targets for violence.

\section{De-escalation at Occupy Wall Street}

The press represented members of the protest as poor protectors of women. A prominent critique from newspapers was Occupy Wall Street handling crime internally 
through de-escalation rather than letting law enforcement handle cases (Buckley, and Flegenheimer A24; Grossman and Firger A21; Schapiro, Einhorn, and Kennedy 5;Taylor A24). De-escalation is a tactic in which members of Occupy Wall Street surrounded the individual responsible for the crime, and using verbal communication, forced the individual to leave the camp or stop their behavior. This alternative to working with law enforcement is part of "community accountability" and is frequently used within activist communities of color and queer groups who often do not find the legal system "safe, relevant or useful" (Chen, Dulani, and Piepzna-Samarasinha 270). Community accountability tries to replicate the helpful functions of law enforcement, such as interrupting harmful acts, determining responsibility, and redressing harm outside the framework of the state (Chen, Dulani, and Piepzna-Samarasinha 270). Cases of sexual violence in these communities often use community accountability because of a history of victim-blaming from police (Chen, Dulani, and Piepzna-Samarasinha, 291). Deescalation is a tactic used within community accountability, and allows groups to work outside the legal system to address problems. Because of the tension and increasing hostility between police officers and Occupy protesters, it makes sense that members of the movement would feel unsafe reporting crimes to the police.

The framing of the process presented by the press failed to address why a deescalation method would be beneficial to protesters compared to engaging with law enforcement. Instead, coverage presented a condescending view of the process to argue that Occupy was not taking crime seriously within the camps and was allowing criminals to continue to wreak havoc. For example, The New York Times referred to the process as "chastising perpetrators of crimes and ejecting them from the park" (Taylor A24) and the 
Wall Street Journal described it as "forcing out all but the worst offenders through public shaming" (El-Ghobashy and Firger). Frequently, these explanations of the process were not quoted from activists at Occupy, but rather by police officers and Mayor Bloomberg, who had a negative view of the movement. By not asking for the activists' opinions of the process, de-escalation was seen almost entirely in a negative light. By failing to put de-escalation into a context of why it was being used, and using negative connotation, the process was seen as illegitimate and not as successful as working with the police.

Paired with dismissive language of de-escalation were quotes from authority figures stating that crime would continue to happen if this process continued to be used. Mayor Bloomberg was frequently used as a newspaper source to discredit the community accountability process with quotes like, "it really allows the criminal to strike again, making all of us less safe," (Buckley, and Fleginheimer A24) and stating that protestors had a "moral obligation to enlist police help" (Taylor A24). Using a credible source like the mayor for quotes allowed his opinion to be valued over that of the protesters. Carter argues that quotes from authority members are used to help frame what is important in the story and to make sense of what is being reported (227). By using Bloomberg as a source, not only do his words carry extra weight, but also he is used to show what is important. So a quote like, "The protesters are endangering the city by failing to report crimes and behaving like vigilantes" helped to the focus the article on how the tactics used by the protestors would not only endanger those who choose to be in the movement, but the city as a whole (Schapiro, Einhorn, and Kennedy 5).

The negative coverage was further exacerbated by the fact that the de-escalation process was constantly referred to in articles that also focused on sexual assault cases 
within the camps (Buckley, and Flegenheimer A24; Grossman and Firger A21; Schapiro, Einhorn, and Kennedy 5; Taylor A24). Sexual assaults were used to discredit the accountability process by stating that the perpetrator of the sexual assault had already gone through the de-escalation process for a previous behavior. In the case of Iketubosin, after protesters kicked him out for sexually assaulting an 18 year-old woman, he was found trying to re-enter the camp while protesters locked arms and attempted to stop him from entering. It was at this point that police were called to the scene (Dejohn, and Kemp). Newspapers also stated that Iketubosin was being investigated for similar crime that occurred in the park days earlier. (Grossman, and Gardiner A21).

One example of the linkage between Iketubosin and de-escalation occurred in The Wall Street Journal. After the article described de-escalation as "encircling troublemakers and publicly shaming them with taunts," the article then mentions the Iketubosin case.

"But that [de-escalation] doesn't always work. In the most recent alleged rape, the victim initially didn't want to report the case to police and the security tried to shame the suspect... When Mr. Iketubosin returned to the park Tuesday, he was recognized and the victim decided to report the incident to police" (Grossman, and Gardiner A21).

De-escalation was used to provoke fear by giving examples of sexual assault cases. If deescalation did not work, that meant rapists would continue to rape. Some protesters argued that sexual assault cases were not typically handled through de-escalation. "If someone is smoking pot or having a beer, we will approach the person and try to moderate it, but if it's theft or a violent crime, we are going to report it to the police" (Schapiro, Einhorn, Kennedy 5). It is unknown how often de-escalation was used in sexual assault cases, but news coverage presented it as the norm. 
Occupy's statement on sexual assault entitled "Transforming Harm and Building Safety: Confronting Sexual Violence at Occupy Wall Street and Beyond," argued that the movement allowed survivors to choose the course of action taken after an assault, whether it be going to the criminal system, or ejecting the perpetrator from the park. They also challenged the idea that Occupy allowed violence to occur arguing,

"We are dismayed by these appalling acts and distressed by the fear among many Occupiers that they have caused, as well as their negative impact on our ability to safely participate in public protest. We have the responsibility to create an alternative to this culture of violence. At OWS, these strategies currently include support circles, counseling, consent trainings, safer sleeping spaces, self defense trainings, community watch, awareness campaigns and other community based processes to address harm" (occupywallst.org).

While Occupy was addressing the problem of sexual assault internally in a variety of different ways, the press did not focus on these areas of education and prevention, only on the area of the failure of de-escalation.

This imagery of rapists running wild preyed on women's fear of violence in public space. With little information about the crime, apart from the fact that the rapist is still free, women in the camps are expected to avoid the area. The scholars, Gordon and Rigard explain that when newspapers presented a vague, general picture of a rape, the women readers concluded the space was not safe and took steps to stay away from the scene of the reported crime (76). It is a safety technique used by women, frequently in public space, but can also be used to blame the victim. In an area known for sexual assaults, the victims at Occupy Wall Street could be seen as foolish or "asking for it," common phrases used to blame sexual assault survivors.

The linkages between sexual assault and de-escalation not only provided a fear of sexual violence, but it blamed the victim of the assault for complying with the de- 
escalation process, which was seen as inappropriate behavior. The New York Daily news reported, "Tony Iketubosin, 26, was later charged with sexual abuse after the woman finally told the police he attacked her on October 25. Like DiGioia, she was hesitant to report the crime at the time" (Schapiro, Einhorn, and Kennedy 5). By not reporting her sexual assault to the police, the unnamed victim allowed Iketubosin to "get away" allowing him to possibly sexually assault another woman. While she is not blamed directly for her own assault, her actions led to other sexual assaults occurring in the camps. Her decision to not report the crime to police and do de-escalation instead, is seen as a negative action.

The case of Lauren DiGioia is another example of a victim being blamed for not reporting. In a New York Daily News article, DiGioia explained how she did not mention her sexual assault to police until she learned that the individual was still in the park. She then recounted her experience with the police and their failure to help her. The police continued to blame her for the assault by stating she should not have slept in the park. DiGioia stated, "I'm a perfect example of somebody who went through the process. I followed all the steps of the law, and I felt victimized by it. I felt like I was a criminal, too." Later she stated, "I don't blame women for not wanting to come forward" (Schapiro, Einhorn, and Kennedy 5). She expresses her understanding and sympathy of why women do not come forward with their assaults. However, the fact that she is stated saying she does not blame the victims means that others are blaming the women of Occupy for not coming forward with their assaults.

What is interesting about coverage of DiGioia's time with the police is the fact that despite her poor experience with the police, the coverage presented it as a better 
process than de-escalation. After DiGioia's interview, the article again mentioned deescalation as endangering the city, "I think it is outrageous and it really allows the criminal to strike again making all of us less safe" (Schapiro, Einhorn, and Kennedy 5). By having the two news article state the events in this way, DiGioia's story is rendered useless. It does not matter if the police treated her poorly, working with the police is still better than the de-escalation process because in the press presents it as the only way to put rapists behind bars. DiGioia is used as an example for what happens to women who join Occupy. Not only are they raped, but also they are blamed by both the police and the press for the fact that sexual assaults are still occurring in the camp.

Newspapers did not just focus on the de-escalation process as the only form of crime prevention within the camp. Articles from The New York Times, Wall Street Journal and New York Daily News also alluded to other forms of keeping protestors from going to the police, including a "no-snitch rule" and "three strikes and you're out policy." These other forms were only discussed in passing, and often were used to make it seem as though Occupy actively tried to stop protestors from coming forward. For example, one police officer stated, "It's hard to gauge true numbers, however, because some protestors say they had been reluctant to come forward about other attacks" (Buckley, and Flegenheimer A24). This shows that women could not trust their fellow protesters to protect them because they would stop them from reporting crime. By not reporting the crime, the illegal activities of the protesters would continue to harm the women in the movement. For women reading about the de-escalation and crime prevention in the park the message became that Occupy Wall Street could protect them. While women were told to go to the police, they received a conflicting message that the police were not 
cooperating with Occupy Wall Street.

\section{Hands off Approach}

The newspaper articles frequently mentioned the rising conflict between police officers and protesters, which led police to develop a hands-off approach for dealing with the protestors (Buckley, and Flegenheimer A24; Grossman, and Firger A21; Schapiro, Einhorn, and Kennedy 5). While quotes by authority figures such as Mayor Bloomberg were used to convince readers why protesters should go to the police with their crimes, the protestors were arguing that law enforcement was ignoring their requests for help. In the words of one protestor, "I've seen the police again and again ignore complaints coming from inside the park." Another protestor said, "We've had the police say you need to deal with that yourselves" (Schapiro, Einhorn, and Kennedy 5). The message received was that the protestors could not turn to police for support, even if they wanted to. This mixed with representations of a lawless society within the camp that created an image that Occupy Wall Street was unsafe for women, and that the people women are supposed to trust (such as the police) could not be counted on if women joined the Occupy movement.

Uncooperative policing was not just the opinion of the protestors, but also by the police themselves. One officer stated in a New York Times article, "We try to maintain a low profile and not antagonize the crowd" (Buckley, and Flegenheimer A24). Rather than actively trying to help with crime control, the police officers left the protesters mostly to their own devices. One article in particular discussed how New York was taking a handsoff approach towards of Occupy Wall Street, and that the city was hoping the protestors would leave when winter temperatures would force them out. While the article 
mentioned, "uniformed officers have remained on the perimeter of the park since the third week of the protest" the police were less than helpful by "rarely venturing in" (Buckley, and Flegenheimer A24). This lack of assistance was not seen as the fault of the police, but rather was blamed on the protesters. Law enforcement believed that having the police in the camps would only cause more violence. Taranto states in his opinion article for the Wall Street Journal, “New York's finest, in fact, are refusing to enforce the law for fear of provoking the so-called protesters to further violence" ("Anarchy Looks Like"). By representing the police as reluctant to enter the camp, women could expect that police would be unable to come to their rescue if something happened. This lack of safety was not the fault of the police, but portrayed as the fault of the protestors.

What message does it send to the women of Occupy when law enforcement is said to be refusing to police the area they are living in? Individuals have been taught that they can trust police officers to protect them, even if that does not reflect their lived experience (Chen 11). With this mentality, women are told that if they are assaulted, they should go to the police to report the crime. With Occupy, there was no guarantee that the police, who were at odds with the protesters, would necessarily protect victims. Women would be blamed for participating in a movement that not even the police would want to venture into for fear of violence. By placing themselves outside the safety of "good men" or police protection, they were at risk of violence from "bad" men. The press presented going to the police as both a viable and an unfeasible solution for the victims, which gave them no clear solution.

The de-escalation process was not seen successful in these articles and going to the police was not an option for the protestors. This placed women in a double bind 
where all their options for handling their assaults have negative outcomes. They could not trust the police who will either ignore their crime, or as with DiGioia, blame them for the assault. Nor could they turn to the protestors and the de-escalation process because the news presented various cases of sexual assault to demonstrate its failure. It was up to the women of Occupy to protect themselves, and the news presented it as not enough.

\section{Risk Reduction at Occupy}

One way women protected themselves was through the construction of a women's only tent, which acted as a safe house for women from sexual assault. The tent was described as a 16 square foot military grade tent frame that could shelter 30 women (Schaprio, Willis, and Karoliszin). The tent was seen by news coverage from The New York Daily News, Wall Street Journal and New York Times, as evidence of a problem of sexual assault within Occupy and yet another poor way of handling sexual assault. The coverage of the tent was described with scare quotes around the tent such as "safe tent" or “safe house." Scare quotes are often used to create sarcasm, or denote disbelief. While possibly used to denote the purpose of the tent, scare quotes also created the feeling that the tent gave the allusion of being safe without actually being safe. One example described the set up of the tent as "to increase the sense of safety for female protestors" (Buckley, and Flegehheimer A24, emphasis mine). The newspapers used the tent and mentions of de-escalation to make it seem that Occupy was doing a poor job protecting the women of Occupy. "Minutes of various Occupy Wall Street meetings and debates in online forums show participants grappling with how to police themselves" (Grossman, and Firger A21). The message was clear: Occupy was unsuccessful at figuring out how to stop violence within the camp. 
The responsibility of stopping sexual assault rested on the shoulders of women, with articles that focused on what women were doing to protect themselves thus solidifying the idea that women were on their own. Mention of the tent was often paired with mention of other risk reduction techniques within the camp. One example of this at Occupy occurred when a protester asked her women's group if “protesters should consider wearing whistles or conduct self-defense training" (Grossman, and Firger A21). Risk reduction puts responsibility for stopping sexual assault on women rather than on the perpetrator by focusing specific strategies to reduce one's risk of rape (Sochting, Fairbrother, and Koch 77). This can be problematic because it ignores the role the perpetrator plays in the assault and can cause the victim to blame herself if the techniques do not work. While risk reduction is helpful in some individual cases, it is primarily based on rape myths and limits women's behavior.

Risk reduction was more than just rape whistles and self-defense; it was women policing the camp themselves. One female protester stated, "It [the women's only tent] will be used to protect ourselves from people out there. I'm sick and tired of women getting taken advantage of, raped and murdered" (Schaprio, Willis, and Karoliszn). Newspapers reported that women constructed posters with pictures of people suspected of sexual assault and posted them around the camps (Grossman, and Firger A21) or creating their own factions within the camp (Schaprio, Willis, and Karoliszn). While it could be seen as an act of empowerment that these women took matters into their own hands, the examples given in these articles, such as putting posters up, and rape whistles were presented as not enough by the press. For example, The New York Times reported that the facilitator of Occupy's LGBT group knew of eighteen women who left the site 
because they feared for their own safety (Buckley, and Flegenheimer A24). Because the coverage made it sound like sexual assaults were rampant within the camp, the women who took matters into their own hands were seen in the same light as someone who put a band-aid on a severed limb. For women reading about these safe zone tents and sexual assault prevention, the message was that sexual assaults were happening in the park and this was Occupy's best attempt at solving them. It was clearly not enough to stop sexual assault from happening.

From the coverage on de-escalation, police‘s hands off approach, and women's tactics to keep safe, Occupy was seen as a dangerous place where women were without the protection of men. Women going into Occupy were on their own when it came to their personal safety, and the examples provided in the news coverage showed that they were not good at protecting themselves. The implication was that women of Occupy could not defend themselves, and the only correct response regarding their safety would be to avoid the park all together. Imagery of rapists attacking multiple women and walking away free fueled a fear that violence would continue to happen to women in Zuccotti Park. Women were blamed for their assaults for being unaccompanied in a dangerous location, and putting themselves willingly into a situation where violence could occur. These victims were then blamed for allowing sexual assaults to continue to happen, despite police being unhelpful, or problems with de-escalation. Rather than question law enforcement, the fault rested on the shoulders of the victims to stop their assaulters, despite the women's few options. By being at Occupy, they assumed the risk and women had to suffer the consequences of that in the eyes of the press. The coverage showed that the best way for women to protect themselves was to stay away. 


\section{Conclusion}

News coverage of the Occupy Wall Street sexual assaults was more complex than traditional coverage of violence against women. More focus was placed on the violence of the protest itself rather than the women who were sexually assaulted. In this way, the discourse of women protesting in public places was overshadowed by negative ideas about Occupy Wall Street by the press. However, by exploring the connections between perceptions of the movement and the comments on sexual assaults occurring, motifs emerged that continued to blame women for the crimes committed against them. These themes focused on women placing themselves in harm's way by participating in Occupy Wall Street.

The three themes of being guilty by association of the men of Occupy, focusing on the physical space of Occupy not being a place for women, and focusing on crime prevention in the Occupy camps all center on how Occupy is a dangerous place and women should not enter the space to keep themselves safe. These ideas use ideology based on traditional gender roles and rape myths that fuel sexual terrorism for women. So while the coverage was not as blatant as more traditional sexual assault coverage when it came to victim blaming, it still stemmed from stereotypical misconceptions about rape. In my final chapter, I will discuss what this coverage means for research on sexual assault news coverage within the wider frame of protests. 


\section{Chapter 5: Conclusion}

Narratives of sexual assault are linked to perceptions about women occupying public space. Victim blaming does not limit itself to individual case coverage, but continues to be seen in sexual assault cases occurring during protests. Like previous research from Benedict, Meyers, and Carter, newspaper coverage of Occupy Wall Street sexual assaults used rape myths to portray the victim as causing her rape to happen. This victim blaming, while not as blatant as coverage of a particular sexual assault case, continues to use gender stereotyping and sexual terrorism to depict women as responsible for their rape.

Newspaper coverage relied on women's fear of rape to demonstrate that Occupy Wall Street was unfit for women's participation. The men of Occupy were presented as deviant, dangerous, and capable of using violence to get what they wanted. As a result, women who were assaulted during the protests were implicitly blamed for their assault because they worked alongside these men. Newspapers used examples of criminal activity within the camps and literary metaphors of common books that feature violent men and boys to display the protestors as unlike typical Americans. In our society, we view deviants of social norms as are likely to sexually assault women than those men who follow the rules dictated by society. By portraying these male activists as dangerous, women were blamed for putting themselves in harm's way by working with them.

Not only representations of men were used to blame women, but so were representations of the camps themselves. The articles focused on the physical space of Occupy as unsafe and unsanitary for women to be in. This area of coverage used the 
myth that there are some places that women should avoid for their own safety. The representations presented of Occupy were reminiscent of a crime-ridden area where danger lurked behind tents. Women, who are taught to avoid dangerous areas for their own safety, were blamed for being in a space where rape was supposedly bound to happen.

Finally, the newspaper coverage blamed victims by alluding to the fact that women who participated in Occupy were without the safety of male protectors, which placed them at risk for sexual assault. The police and their fellow protesters were unable to guard women from sexual assault, with coverage representing the protestors as letting criminals escape and continue to harm women. Law enforcement was unable to help within the camps and the protesters would not work with the police, both of which responses left women without a protector.

Women were blamed for not acting within traditional gender roles in public, by their refusal to acknowledge that some areas are out of bounds for them. By claiming space alongside their fellow male protesters, women were seen as easy targets for sexual assault because they failed to follow social norms associated with their gender. The negative perceptions of Occupy Wall Street influenced these blame the victim narratives which vilified both the movement and the women involved.

One of the main focal points of this research demonstrates that while blame the victim narratives were present in the news coverage of the Occupy Wall Street sexual assaults, the victims were not central to the coverage itself. Even though the background of these victims is unknown, they were still blamed because of their association with Occupy Wall Street. In addition, the coverage of the sexual assaults was secondary to the 
presentation of Occupy Wall Street. Unlike individual cases of sexual assaults, the focus of these news stories was on why Occupy Wall Street was a problem, not about the crimes themselves. Occupy Wall Street was presented as dangerous, crime infested and prone to violence. Sexual assaults were seen as an example of this problem, and used as a reason for why the movement should end. Women were blamed for being at Occupy and yet their assaults were used as justification for the shutdown of the movement. Not only does this show the survivors of gender based violence as victims, but it removes their agency in the movement. These women are not seen as participants of Occupy Wall Street, but casualties of it.

The coverage of sexual assault confirmed rape myths in our culture by removing the role our institutions plays in socializing individuals to accept rape culture. Not only does this reinforce harmful myths about sexual assault, but it fails to ask the question "why is sexual assault occurring?" Sexual assault was seen as a natural outcome of the protests, and something that could have easily been avoided if the movement was stopped earlier on. Using sexual assault as a justification for ending Occupy Wall Street delegitimized the activists and failed to account for the fact that sexual assault is a common experience in the United States. We live in a culture of violence in which sexual assault is excused, condoned, and ignored. Sexual assault is rarely seen as a societal problem unless it is used to uphold the status quo. In the case of Occupy Wall Street, the movement was challenging capitalism and wealth inequality and mentioning the sexual assaults discredited their goals and political work. The articles failed to address how the sexual assaults would impact the victims, or how the assaults were part of the larger issue of violence against women. This coverage demonstrates that ending Occupy Wall Street 
was more important than ending sexual assault.

Using these results, future studies should continue to question how rape myths influence women's participation in the public sphere. As it relates to Occupy Wall Street, researchers should explore through interviews how women in the movement challenged this discourse, or how they reasoned why they should stay in the camps. Interviews would help to demonstrate how ideas of sexual terrorism are challenged and maintained by women in social movements. While this analysis showed characteristics of the discourse, interviews would allow for a more complex understanding of how the discourse of sexual assault myths influences women's participation in social movements. It would also be beneficial to examine more independent newspapers and blogs to see how their coverage of the assaults varied from the more mainstream reports. This would add more depth and understanding of the connections between the women of Occupy Wall Street and sexual assault cases.

In addition, researchers should explore other representations of sexual assault within protests to see how these themes are similar or modified depending on how the social movement is viewed by the press. For example, if a group of women were actively representing feminine gender roles, such as Mujeres de Negros in Mexico, how would their sexual assaults be covered? Questions such as, "In what ways do perceptions of particular social movements influence blame the victim narratives?" and "Do the identities of the protesters create particular themes within sexual assault cases?" will help to expand our working definitions of rape myths and see the connections between safety, public space, and women's participation in social movements. 
The media, like other institutions, traditionally does not challenge social norms, but rather enforces the status quo. The construction of what is shown in various forms of media, whether it be newspapers, television or music, is usually produced and promoted by those who have privilege in society. Positions of power in newsrooms are still mainly held by white men, and these individuals decide what stories get told and how those stories are represented. Often this means the viewpoint presented is a masculine perception of the world. Due to the fact that much of the media we see is constructed from this point of view, media serves a crucial role in reinforcing this masculine perspective and is used to show what is deemed appropriate behavior in our society. It also important to acknowledge that that media is interconnected with other institutions in society that work together to uphold the status quo. Institutions reinforce the perception of the ruling elite, and their viewpoints. These opinions do not appear out of thin air, but are based in ideology.

In the case of Occupy Wall Street coverage, newspapers had a stake in whether Occupy Wall Street successfully completed their goal of economic reform because many of them were supported by Wall Street. Mainstream newspapers have a competing interest with the message of Occupy Wall Street, so shaping the movement as dangerous and disorganized removes credibility of the protesters and their goals. Also mainstream news is a business, and that business is to sell papers. By focusing on the sexual assault cases within Occupy, they are not only discrediting the movement but shaping a story that will sell. Stories of violence are sensationalized and scrutinized by the press because violence against women does sell papers (Carter 223). Future research should explore the 
connection between news media and their relationships with the outcome of social movements.

Ideology also influences the role of media in shaping and reflecting public opinion. Newspapers play a dominant function informing the public and constructing how they should see these events. One ways of constructing these issues is through the concept of newsworthiness, or what is worthy of being printed. A central component of newsworthiness is conflict, in which media presents two opposing viewpoints to an issue or event. Often, the construction of this leads to one side of the issue as "right" and the other as "wrong." In the case of Occupy Wall Street, the newspapers constructed the image that Occupy was an incorrect way of protesting and did not reflect appropriate behavior. Occupy's poor presentation was then used to shape public opinion of the protests. This viewpoint was not isolated to one paper, but expanded to most of the mainstream coverage. While independent papers could have challenged this perception, larger papers dominated public opinion because of their easier accessibility to the public both in cost and access. Without an equally prominent opposing viewpoint, these mainstream papers controlled how the public should feel about Occupy Wall Street and the survivors of the sexual assaults.

The survivors of sexual assault were not just victims, but activists raising awareness about their concerns. News coverage blamed them without giving a voice to why it was important to be in Zuccotti Park. Women's actions in Occupy Wall Street were ignored in the coverage of sexual assault, and they were not seen as political actors. If women are to be seen as full democratic citizens in the United States, they must be able to voice their concerns in the public sphere and be seen as such by the media. If women 
are afraid to venture into political action for fear of sexual assault or if they are reduced to their assault, they are not full participants in our society. 
Appendix A

Occupy's Statement on Sexual Assault

\section{Transforming Harm \& Building Safety: Confronting Sexual Violence At Occupy Wall Street \& Beyond}

New York, November 4, 2011: We are writing this statement to inform our fellow occupiers about an incident of sexual assault at Occupy Wall Street (OWS) and the response to it. We are also writing this statement to respond to media accounts that blame the survivor, and that attempt to use this horrific incident to attack OWS. We write this statement as supporters of OWS, as fellow survivors, and as allies.

On the morning of October 29, a woman participating in OWS was sexually assaulted at Liberty Square. The person who she identified as having assaulted her was arrested on November 1 for a previous assault and is currently incarcerated.

On the morning of the assault, the survivor was accompanied to the hospital by a group of women from OWS, including a social worker, to support her and act as advocates. From the moment the incident was discovered to the present time, the survivor has been surrounded by a network of allies and trained advocates offering resources to provide emotional, medical, and legal support. At every step of the process, and in line with the core principles of survivor support, her wishes as to how she wanted to proceed have been honored, and information from a range of sources has been provided to her about her options. The survivor knew immediately that she wanted to make sure that the person who assaulted her did not harm anyone else at OWS. Community members honored this demand by asking that this person to stay off site, and, when he refused, monitored his activity and ejected him from the space. 
These efforts provided the survivor with the time and space to carefully review the options available to her. Following two days of discussion with family, friends, supporters, and anti-violence advocates, the survivor decided to make a report to the police and to push for a criminal investigation and prosecution. Supporters from OWS accompanied her to the police station, and will continue to support her throughout the legal process.

We have been saddened and angered to observe some members of the media and the public blame the survivor for the assault. A survivor is never at fault. It is unacceptable to criticize a survivor for the course of action they chose to take or their community for supporting them in that choice. Additionally, we were troubled at the time of her report that responding police officers appeared to be more concerned by her political involvement in OWS than her need for support after a traumatic incident of sexual violence. A survivor is not at fault for being assaulted while peacefully participating in a public protest to express their political opinions. We are aware that this is one of several known cases of sexual assault that have occurred at OWS. We are dismayed by these appalling acts and distressed by the fear among many Occupiers that they have caused, as well as their negative impact on our ability to safely participate in public protests. We have the right to participate in peaceful protests without fear of violence.

We are also concerned that segments of the media have attempted to use this incident as another way to disingenuously attack and discredit OWS. It is reprehensible to manipulate and capitalize on a tragedy like this to discredit a peaceful political movement. OWS exists within a broader culture where sexual assault is egregiously 
common: someone in the US is sexually assaulted every 2 minutes, most assaults are never reported, and most rapists are never held to account. We live in a culture of violence in which sexual assault is often ignored, condoned, excused and even encouraged. We note that it is particularly difficult for survivors of assault at OWS to feel confident in reporting crimes to the NYPD - the NYPD's unjustifiably aggressive and abusive policing of OWS has undermined trust in the police force amongst protesters. As individuals and as a community, we have the responsibility and the opportunity to create an alternative to this culture of violence. Advocates, some of whom are survivors themselves, have worked for decades to address sexual violence generally. We are working for an OWS and a world in which survivors are respected and supported unconditionally, where they are supported to come forward, and where every community member takes responsibility for preventing and responding to harm. We are redoubling our efforts to raise awareness about sexual violence. This includes taking preventative measures such as encouraging healthy relationship dynamics and consent practices that can help to limit harm.

We are creating and sharing strategies that educate and transform our community into a culture of consent, safety, and well-being. At OWS, these strategies currently include support circles, counseling, consent trainings, safer sleeping spaces, self-defense trainings, community watch, awareness campaigns, and other evolving community-based processes to address harm. We encourage survivors to connect with support and advocates, and to access medical, legal, and social services, as well as available community-based options, many of which are listed below. We stand together as a community to work towards the prevention of sexual violence and harassment and to 
provide unwavering support for anyone who has been assaulted. We commit to creating a culture of visibility, support, and advocacy for survivors, and of accountability for people who have committed harm.

With hope and solidarity, Members of the survivor's support team at Occupy Wall Street 


\section{Appendix B}

Newspapers Articles Examined

Buckley, Cara, Matt Flegenheimer. "At Scene of Wall St. Protest, Rising Concerns About Crime. The New York Times. Nov. 08 2011. ProQuest. Web. 8 Feb. 2014.

Crovitz, Gordon L. “Are Tent Cities Free Speech? The First Amendment Does Not Protect Behavior that Threatens Health and Safety." Wall Street Journal. Nov. 21 2011.ProQuest. Web. 8 Feb. 2014.

Crovitz, Gordon L. "Occupy AstroTurf; the 'Movement' Faded as Soon as the Tents were Removed." Wall Street Journal. Jan 29 2012. ProQuest. Web. 8 Feb. 2014.

Dejohn, Irving, Joe Kemp. "Arrest Made in Occupy Wall St. Sex Attack; Suspect Eyed in Another Zuccotti Groping.” New York Daily News. Nov 02 2011. ProQuest. Web. 8 Feb. 2014.

El-ghobasy, Tanner, Jessica Firger. "Wall Street Protesters Are Opting for Trials." Wall Street Journal. Nov 04 2011. ProQuest. Web. 8 Feb. 2014.

Gerson, Michael. "Radicals on the Rise." The Washington Post. Nov 08 2011. ProQuest. Web. 8 Feb. 2014.

Gowen, Annie. "Love Amid the Tents." The Washington Post. Jan 08 2012. ProQuest. Web. 8 Feb. 2014.

Grossman, Andrew, and Jessica Firger. "Security Concerns Emerge at Zuccotti.” Wall Street Journal, Eastern edition ed. Nov 03 2011. ProQuest. Web. 8 Feb. 2014. Grossman, Andrew, and Pervaiz Shallwani. "Protesters' Dilemma: Less Space to Occupy." Wall Street Journal, Eastern edition ed. Nov 08 2011. ProQuest. Web. 
8 Feb. 2014.

Grossman, Andrew, Sean Gardiner. "Man Arrested in Sex Assaults at Occupy Wall Street." Wall Street Journal, Eastern edition ed. Nov 02 2011. ProQuest. Web. 8 Feb. 2014.

Jacobs, Shayna. "Police Hunt Thug Jackie Barcliff Suspected in Sexual Assault on Occupy Wall Street Protester.” New York Daily News. Sep. 13 2012. ProQuest. Web. 8 Feb. 2014.

Kengor, Paul G. "In 1920, Americans Saw Carnage of Class Warfare." USA TODAY. Nov 09 2011. ProQuest. Web. 8 Feb. 2014.

Knight, Robert. "Massaging the News for the Masses." Washington Times. Oct 31 2011. ProQuest. Web. 8 Feb. 2014 .

Popper, Nathaniel, Geraldine Baum and Tina Susman. "Where does the Occupy Movement Go Now?" Los Angeles Times. Nov 16 2011. ProQuest. Web. 8 Feb. 2014 .

McGurn, William. "Main Street: Bloomberg's Broken Windows." Wall Street Journal, Eastern edition ed.Nov 08 2011. ProQuest. Web. 8 Feb. 2014 .

Saslow, Eli, and Colum Lynch. "The Occupy Movement: More Trouble than Change?" The Washington Post. Nov 16 2011. ProQuest. Web. 8 Feb. 2014 . Schapiro, Rich, Erin Einhorn and Helen Kennedy. "Are They Here to Help? Protesters, Cops at Odds Over Crime." New York Daily News: 5. Nov 04 2011. ProQuest. Web. 8 Feb. 2014.

Schapiro, Rich, Kerry Wills and Henrick Karoliszn. “Occupy Wall Street Builds Tent as 'Safe House' to Protect Female Protesters.” New York Daily News: 5. Nov 04 
2011. ProQuest. Web. 8 Feb. 2014.

Taylor, Katie. "Reports of Unreported Crime at Zuccotti Park Bother Bloomberg" The New York Times. Nov 03 2011. ProQuest. Web. 8 Feb. 2014.

Taranto, James. "Better Late than Never; After almost Two Months, Mayor Bloomberg Finally Cleans Obamaville." Wall Street Journal. Nov 15 2011. ProQuest. Web. 8 Feb. 2014.

Taranto, James. "The Obamaville Riots; should the Liberal Media be Held Responsible for Left-Wing Violence?" Wall Street Journal. Nov 07 2011. ProQuest. Web. 8 Feb. 2014.

Taranto, James. "This is what Anarchy Looks Like; More Stories of Violence at Obamaville." Wall Street Journal. Nov 08 2011. ProQuest. Web. 8 Feb. 2014 . Washington Times. "Occupy Movement Evicted." Washington Times. Nov 17 2011. ProQuest. Web. 8 Feb. 2014 .

Wolf, Milton R., "My Challenge to Occupy Wall Street." Washington Times. Nov 02 2011. ProQuest. Web. 8 Feb. 2014 . 


\section{Work Cited}

Beauvoir, Simone De. The Second Sex. New York: Modern Library, 1968. Print.

Benedict, Helen. Virgin or Vamp: How the Press Covers Sex Crimes. New York: Oxford UP, 1992. Print.

Bevacqua, Maria. Rape on the Public Agenda: Feminism and the Politics of Sexual Assault. Boston: Northeastern UP, 2000. Print.

Buckley, Cara, Matt Flegenheimer. "At Scene of Wall St. Protest, Rising Concerns About Crime. The New York Times. Nov. 08 2011. ProQuest. Web. 8 Feb. 2014.

Cahill, Ann J. Rethinking Rape. Ithaca: Cornell UP, 2001. Print.

Carter, Cynthia, Gill Branston, and Stuart Allan. "When the 'Extraordinary' Becomes 'Ordinary': Everyday News Coverage of Sexual Violence." News, Gender, and Power. London: Routledge, 1998. 219-32. Print.

Chen, Ching-In, Jai Dulani, and Leah Lakshmi Piepzna-Samarasinha. The Revolution Starts at Home: Confronting Intimate Violence within Activist Communities. New York: South End, 2011. Print.

Condon, Stéphanie. "Feeling Unsafe in Public Places: Understanding Women's Fears." Revue Française de Sociologie 48.5 (2007): 101-128.

Crenshaw, Kimberle. "Mapping the Margins: Intersectionality, Identity Politics, and Violence Against Women of Color." Stanford Law Review 43.6 (1991): 1241 299. Print.

Cuklanz, Lisa M. Rape on Trial: How the Mass Media Construct Legal Reform and Social Change. Philadelphia, PA: University of Pennsylvania, 1996. Print. 
Davenport, Christian, Hank Johnston, and Carol McClurg Mueller. Repression and Mobilization. Minneapolis: University of Minnesota Press, 2005.

DeLuca, Kevin M., Sean Lawson, and Ye Sun. "Occupy Wall Street on the Public Screens of Social Media: The Many Framings of the Birth of a Protest Movement." Communication, Culture \& Critique 5.4 (2012): 483-509.

Edwards, Katie M., Christina M. Dardis, Christine A. Gidycz, Jessica A. Turchik, and Nicole Reynolds. "Rape Myths: History, Individual and Institutional-level Presence, and Implication for Change." Sex Roles 65 (2011): 761-73. Print.

Einwohner, Rachel, Jocelyn Hollander, and Toska Olson. "Engendering Social Movements: Culture Images and Movement Dynamics." Gender and Society 14.5 (2000): 679-99. Print.

Eldridge, Adam. "Public Panics: Problematic Bodies in Social Space." Emotion, Space and Society 3.1 (2010): 40-44.

Evans, Sara M. Personal Politics: The Roots of Women's Liberation in the Civil Rights Movement and the New Left. New York: Knopf : Distributed by Random House, 1979. Print.

Fletcher, Pamela R., Emilie Buchwald, and Martha Roth. Transforming a Rape Culture. Minneapolis, MN: Milkweed Editions, 2005. Print.

Ford, Linda. Iron-Jawed Angels: The Suffrage Militancy of the National Woman's Party, 1912-1920. Lanham, MD: University of America, 1991. Print.

Franiuk, R., J. L. Seefelt, S. L. Cepress, and J. A. Vandello. "Prevalence and Effects of Rape Myths in Print Journalism: The Kobe Bryant Case." Violence Against Women 14.3 (2008): 287-309. Print. 
Gardner, Carol Brooks. Passing By: Gender and Public Harassment. Berkeley: University of California, 1995. Print.

George, William H., and Lorraine J. Martínez. "Victim blaming in rape: Effects of Victim and Perpetrator race, type of rape, and participant racism." Psychology of Women Quarterly 26.2 (2002): 110-119.

Gitlin, Todd. Occupy Nation: The Roots, the Spirit, and the Promise of Occupy Wall Street. New York: It, 2012. Print.

Gordon, Margaret T., and Stephanie Riger. The Female Fear. New York: Free, 1989. Print.

Hawkesworth, M. E. Political Worlds of Women: Activism, Advocacy, and Governance in the Twenty-first Century. Boulder, CO: Westview, 2012. Print.

Herman, Dianne. "The Rape Culture." Women, a Feminist Perspective. Palo Alto, CA: Mayfield Pub., 1975. Print.

Hermes, Joke. "Feminism and the Politics of Method." Questions of Method in Cultural Studies (2006): 154.

Hesse-Biber, Sharlene Nagy. Feminist Research Practice: A Primer. Los Angeles: SAGE Publications, 2014. Print.

hooks, bell. Feminist Theory: From Margin to Center. Boston, MA: South End, 1984. Print.

Kissling, E. A. "Street Harassment: The Language of Sexual Terrorism." Discourse \& Society 2.4 (1991): 451-60. Print.

Kurtz, Hilda E. "Gender and Environmental Justice in Louisiana: Blurring the Boundaries of Public and Private Spheres." Gender, Place \& Culture: A Journal of Feminist 
Geography 14.4 (2007): 409-26. Print.

Lonsway, Kimberly A., and Louise F. Fitzgerald. "Rape Myths In Review." Psychology of Women Quarterly 18.2 (1994): 133-64. Print.

Madriz, Esther. Nothing Bad Happens to Good Girls: Fear of Crime in Women's Lives. Berkeley: University of California, 1997. Print.

Meyers, Marian. News Coverage of Violence against Women: Engendering Blame. Thousand Oaks: Sage Publications, 1997. Print.

McGuire, Danielle L. At the Dark End of the Street: Black Women, Rape, and Resistancea New History of the Civil Rights Movement from Rosa Parks to the Rise of Black Power. New York: Alfred A. Knopf, 2010. Print.

Moorti, Sujata. Color of Rape: Gender and Race in Television's Public Spheres. Albany: State University of New York, 2002. Print.

Naples, Nancy, ed. Community Activism and Feminist Politics: Organizing across Race Class and Gender. New York: Routledge, 1998. Print.

OccupyWallSt. "Transforming Harm \& Building Safety: Confronting Sexual Violence at Occupy Wall Street \& Beyond." Occupy Wall Street. N.p., 04 Nov. 2011. Web. 08 Dec. 2013.

Reel, Guy. “A Dirty Dozen: Twelve of the 'Best' Tabloids of all Time.” American Journalism, 27.2 (2010): 138-146. Print.

Ross, Karen, and Carolyn M. Byerly. "Media Coverage of Sexual Violence against Women and Children." Women and Media: International Perspectives. Malden, MA: Blackwell,

Ruby, Jennie. "The Grammar of Male Violence." Off our Backs (2004): 26-27. Print. 
Ryan, Kathryn. "The Relationship between Rape Myths and Sexual Scripts: The Social Construction of Rape." Sex Roles 65 (2011): 744-82. Print.

Sheffield, Carole. "Sexual Terrorism: The Control of Women." Analyzing Gender: A Handbook of Social Science Research. Newbury Park, CA: Sage Publications, 1987. N. pag. Print.

Sochting, Ingrid, Nichole Fairbrother, and William J. Koch. "Sexual Assault of Women Prevention Efforts and Risk Factors." Violence Against Women 10.1 (2004): 7393.

Staeheli, Lynn. "Publicity, Privacy and Women's Political Action." Environment and Planning D: Society and Space 14.5 (1996): 601-19. Print.

Trichter, Jonathan, and Chris Page. Tabloids, Broadsheets, and Broadcast News: What New York City Residents Think About Their Hometown Media. Rep. New York: Pace Poll Survey Research Study, 2004. Print.

West, Guida, and Rhoda Lois Blumberg. Women and Social Protest. New York: Oxford UP, 1990. Print.

Valentine, Gill. "The Geography of Women's Fear." Area 21.4 (1989): 385-90. Print. 